\title{
Silver-polymethylhydrosiloxane nanocomposite coating on anodized aluminum with superhydrophobic and antibacterial properties
}

Henry Agbe ${ }^{1}$, Dilip Kumar Sarkar ${ }^{1 *}$, X.-Grant Chen $^{1}$, Nathalie Faucheux ${ }^{2}$,Gervais Soucy ${ }^{2}$, JeanLuc. Bernier ${ }^{3}$

${ }^{1}$ Department of Applied Science, University of Québec at Chicoutimi, Aluminum Research Center - REGAL, Chicoutimi, QC, Canada, G7H 2B1.

${ }^{2}$ Department of Chemical and Biotechnological Engineering, Université de Sherbrooke, Sherbrooke, QC, Canada, J1K2R1

${ }^{3}$ A3 Surfaces, Chicoutimi, QC, Canada, G7H 1 Z6.

KEYWORDS:Ag nanocomposite; anodized aluminum; superhydrophobic coating; antibacterial properties; anti-biofouling surface.

\begin{abstract}
:
Biofilm formation on both animate and inanimate surfaces serves as an ideal bacterial reservoir for the spread of nosocomial infections. Designing surfaces with both superhydrophobic and antibacterial properties can help reduce initial bacterial attachment and subsequent biofilm formation. In the present study, a two-step approach is deployed to fabricate silverpolymethylhydrosiloxane (Ag-PMHS) nanocomposites, followed by a simple dip-coating deposition on anodized Al. Ag-nanoparticles (Ag-NPs) are synthesized in-situ within a PMHS polymeric matrix. Morphological features of Ag-PMHS coating observed by scanning electron
\end{abstract}


microscopy shows heterogeneous micro-nano structures. The chemical compositions of these coatings were characterized using X-ray diffraction and attenuated total reflection-Fourier Transform infrared spectroscopy, which indicate the presence of a low-energy PMHS polymer.

The as-synthesized Ag-PMHS nanocomposite demonstrated excellent antibacterial properties against clinically relevant planktonic bacteria, with zone of inhibition values of $25.3 \pm 0.5,24.8 \pm$ 0.5, and $23.3 \pm 3.6 \mathrm{~mm}$ for Pseudomonas aeruginosa (P.A) (gram -ve), Escherichia coli (E-coli) (gram -ve), and Staphylococcus aureus (S.A) (gram +ve), respectively. The Ag-PMHS nanocomposite coating on anodized Al provides an anti-biofouling property with an adhesion reduction of $99.0 \%, 99.5 \%$, and $99.3 \%$ for Pseudomomas aeruginosa (P.A), Escherichia-Coli (E-coli) and Staphyloccocus aureus (S.A), respectively. Interestingly, the coating maintained a stable contact angle of $158^{\circ}$ after 90 days of immersion in saline water $(3.5 \mathrm{wt} . \% \mathrm{NaCl}, \mathrm{pH}=7.4)$.

The Ag-PMHS nanocomposite coating on anodized Al described herein demonstrates excellent antibacterial and anti-biofouling properties, owing to its inherent superhydrophobic property

\section{INTRODUCTION}

Bacteria colonize material surfaces and develop into a community (in extracellular polymeric substance (EPS) matrix), herein referred to as a biofilm ${ }^{1}$. The pathogenicity of bacteria in a biofilm differs from their free-floating planktonic cells. A biofilm offers bacteria certain advantages such as the ability to acquire resistant strains ${ }^{2}$, intercellular communication ability to regulate gene expression via quorum sensing $(\mathrm{QS})^{3}$, and the ability to evade antimicrobial attacks ${ }^{4}$. Furthermore, 
a biofilm provides a safe haven for the spread of nosocomial infections ${ }^{5}$. It is believed that multidrug-resistant (MDR) bacteria in biofilms (Staphyloccocus aureus (S.A), Pseudomomas aeruginosa (P.A), and Escherichia-Coli (E-coli)) are the leading cause of nosocomial infections or heathcare-associated infections ${ }^{6-7}$. Therefore, designing anti-biofouling surfaces for preventing initial bacterial attachment and subsequent biofilm formation using superhydrophobic coatings has recently gained significant interest ${ }^{8-10}$. However, the ability of superhydrophobic coatings to repel bacterial adhesion in humid environments is limited, mainly due to the loss of property of water repellency ${ }^{11-14}$. To achieve a robust and long-term anti-biofouling surface, it is desirable to incorporate bactericides such as Ag. Hence, fabricating superhydrophobic coatings with inherent antibacterial properties may serve as an ideal strategy to prevent initial bacterial adhesion and subsequent biofilm formation.

Few studies have reported the fabrication of anti-biofouling surfaces (utilizing superhydrophobicity) with inherent antibacterial properties ${ }^{15-17}$. Wang, Z. et al. ${ }^{17}$ fabricated mussel-inspired polydopamine superhydrophobic Ag coatings via a facile Ag mirror reaction and evaluated both the antibacterial and superhydrophobic properties against S.A and E-coli. They demonstrated that the superhydrophobic Ag coating exhibited antibacterial properties with a zone of inhibition (ZOI) of $\sim 3.0 \pm 0.3 \mathrm{~mm}$ and stability of 60 days. Meanwhile, Zhang, M. et al. ${ }^{15}$ fabricated a $\mathrm{Ag} / \mathrm{Cu}$ bimetallic hierarchical architecture coating on a copper substrate with both superhydrophobic and antibacterial properties using a facile galvanic replacement reaction, followed by a simple thermal oxidation process. The study indicated both antibacterial and superhydrophobic properties but failed to report the anti-biofouling property. Furthermore, Ozkan, E. et al. ${ }^{18}$ engineered a superhydrophobic antibacterial copper coating via aerosol-assisted chemical vapor deposition (AACVD) with antibacterial properties against E. coli and S.A. Even 
though the superhydrophobic coatings of these studies were well above $150^{\circ}$ in contact angle (CA), the antibacterial efficiency was low. Moreover, synthesis methods such as AACVD are expensive. For practical applications, a simple, cost-effective, and scalable process would be the sol-gel synthesis of superhydrophobic Ag nanocomposite coatings on metals such as Al.

It has been reported that polymethylhydrosiloxane (PHMS) can be utilized to synthesize silver nanoparticles (Ag-NPs) via the sol-gel process owing to its ability to reduce $\mathrm{Ag}^{+}$to $\mathrm{Ag}^{0}$ in-situ, due to the $(\mathrm{Si}-\mathrm{H})$ moiety on the siloxane backbone ${ }^{19-20}$. Several groups have explored the synthesis of Ag-NPs via PMHS reduction ${ }^{19-22}$. For example, Shang, R. et al. ${ }^{21}$, reported the synthesis of an Ag-NP-embedded PMHS hybrid material with high surface area, good mesoporosity, and narrow size distribution. Similarly, Zuo,Y. et al. ${ }^{19}$ synthesized hollow $\mathrm{Ag}-\mathrm{SiO}_{2}$ composite spheres that exhibited high catalytic performance. Additionally, our research group has recently fabricated superhydrophobic coatings on $\mathrm{Al}$ using a $\mathrm{TiO}_{2} / \mathrm{PMHS}$ sol-gel process.

In spite of significant efforts on silicone-based superhydrophobic coatings in applications of antibacterial properties, the adhesion reduction performance of bacteria has been rather low (79 $95 \%)^{23-24}$. Furthermore, the applicability of such coating is limited due to the degradation with time. As Ag has natural properties to kill bacteria, incorporating it in silicone-based superhydrophobic coatings such as polymeric PMHS could reduce the bacterial adhesion (antibiofouling) and improve the overall longevity of such coatings even after the loss of superhydrophobicity. Surprisingly, fabrication of superhydrophobic Ag-PMHS nano-composite coatings with inherent antibacterial and anti-biofouling properties is yet to be reported in the literature. 
The objective of this study is to fabricate a novel coating of Ag-PMHS nanocomposites on anodized Al via the sol-gel process for antibacterial and anti-biofouling applications. We hypothesize that the in-situ synthesis of Ag-NPs within a PMHS polymeric matrix, anchored within an anodized Al oxide (AAO) substrate, could enhance the adhesion, durability, and stability of superhydrophobic Ag-PMHS nanocomposites. PMHS not only serves as a reducing agent, but also a morphological controlling agent for holding and presumably triggering controllable $\mathrm{Ag}^{+}$ release. The excellent antibacterial and antibiofouling properties, owing to the inherent superhydrophobicity of the Ag-PMHS nanocomposite coating on anodized Al, are demonstrated.

\section{MATERIALS AND METHODS}

Synthesis of Ag-PMHS nanocomposite. Ethanoic polymethylhydrosiloxane (PMHS) ( $\geq 97 \%$, VWR) stock solution was sonicated (Branson ${ }^{\circledR}$ Ultrasonic Bath, $230 \mathrm{Vac}, 50 \mathrm{~Hz}$ ) for $15 \mathrm{~min}$ for dispersion. Subsequently, 0.08 M PMHS was added to mineral spirit while stirring using a magnetic Teflon stirrer rotating at $500 \mathrm{rpm}$ at $55^{\circ} \mathrm{C}$ for $30 \mathrm{~min}$. Next, Ammonium hydroxide 11.2 $\mathrm{M}\left(28-30\right.$ wt. $\%$ of $\left.\mathrm{NH}_{3},-\mathrm{VWR}\right)$ was added dropwise to the suspension to achieve a $\mathrm{pH}$ of 11 . The sol-gel reaction was allowed to age briefly for $30 \mathrm{~min}$. Subsequently, $0.08 \mathrm{M} \mathrm{AgNO}_{3}$ (VWR) solution was added dropwise to the above suspension according to the $\mathrm{Ag}^{+} / \mathrm{Si}-\mathrm{H}$ molar ratio (Table 1). The as-synthesized product was stirred vigorously using a magnetic Teflon stirrer rotating at $700 \mathrm{rpm}$ at $55^{\circ} \mathrm{C}$ for an additional $15 \mathrm{~min}$. 
Table 1: Ag-PMHS molar ratio.

\begin{tabular}{|c|c|c|}
\hline Samples & $\mathbf{A g}^{+} / \mathbf{S i}-\mathbf{H}$ molar ratio & Volume of Mineral \\
& & Spirit $(\mathbf{m L})$ \\
\hline 1 & $50: 1$ & 15 \\
\hline 2 & $50: 2$ & 15 \\
\hline 3 & $50: 30$ & 15 \\
\hline 4 & $50: 40$ & 15 \\
\hline 5 & $50: 50$ & 15 \\
\hline 6 & $2: 50$ & 15 \\
\hline 7 & $1: 50$ & \\
\hline
\end{tabular}

Fabrication of Ag-PMHS nanocomposite coating on AAO substrates. The as-synthesized AgPMHS nanocomposite was loaded with premium room-temperature vulcanized (RTV) adhesive silicone. The RTV silicone $(0.0 \%(\mathrm{w} / \mathrm{v}), 0.4 \%(\mathrm{w} / \mathrm{v}), 2.0 \%(\mathrm{w} / \mathrm{v}), 4.0 \%(\mathrm{w} / \mathrm{v}), 6.0 \%(\mathrm{w} / \mathrm{v})$, and 8.0\% (w/v))-loaded Ag-PMHS nanocomposite was sonicated to obtain a homogeneous dispersion. The Ag-PMHS polymeric solution above was coated on an AAO substrate through a 5-min dip coating deposition process, followed by room-temperature drying for $24 \mathrm{~h}$. The anodization process was performed as follows: A 1" $\times 2$ " $\mathrm{Al}$ (AA6061) was ultrasonically degreased in a soapy solution and cleaned in deionized water, followed by $1 \mathrm{M} \mathrm{NaOH}$ (VWR) chemical etching at $55^{\circ} \mathrm{C}$ to remove a superficial oxide layer. Then the etched substrate was further sonicated in 
distilled water. Afterward, etched $\mathrm{Al}$ substrate was subsequently immersed in $\mathrm{HNO}_{3}$ solution (10 wt.\%, VWR) for desmutting, followed by rinsing in distilled water. Next, both etched-and asreceived $\mathrm{Al}$ substrates were used as anode and cathode, respectively. The electrochemical cell was equipped with a $600 \mathrm{~W}$ direct current power supply (Ametek Sorensen DCS 100-12E, Chicoutimi, QC, Canada), a quartz-jacketed beaker with cold circulating water $\left(5^{\circ} \mathrm{C}\right)$, and a small magnetic Teflon stirrer, rotating at $2000 \mathrm{rpm}$. Anodization was performed in the galvanostatic mode at a current density of $40 \mathrm{~mA} / \mathrm{cm}^{2}$ and electrolyte concentration of ( $\mathrm{H}_{2} \mathrm{SO}_{4}-15$ wt.\%,-VWR), with varying times of 30, 60, and $120 \mathrm{~min}$. During anodization, the two electrodes were separated in parallel by a distance of $1.5 \mathrm{~cm}$. For quality control and reproducibility, each experiment was triplicated.

Sample characterization. The surface morphology and elemental analysis of the Ag-PMHS nanocomposite were performed using scanning electron microscopy (SEM, JEOL JSM-6480 LV), equipped with energy dispersive X-ray spectroscopy (EDX). The crystalline structure and chemical composition of the synthesized Ag-PMHS nanocomposite were analyzed with X-ray powder diffraction (XRD) (a Bruker D8 Discover system) and attenuated total reflection-Fourier transform infrared (ATR-FTIR, Perking Elmer Spectrum One), respectively. Static CA was measured with a First Ten Angstorm CA goniometer using $10 \mu \mathrm{L}$ of deionized water drops. The roughness of the Ag-PMHS nanocomposite coating on anodized Al was measured using a MicroXAM-100 HR 3D surface profilometer.

Antibacterial susceptibility assay. The model bacterial strain, i.e., S.A (ATCC 6538), P.A (ATCC 9027), and E-coli (ATCC 8739-Hardy Diagnostics) were grown overnight from a frozen 
$\left(-80{ }^{\circ} \mathrm{C}\right)$ stock in tryptic soy broth (TSB-Hardy Diagnostics) at $37^{\circ} \mathrm{C}$, re-inoculated in fresh TSB $\left(37^{\circ} \mathrm{C}\right)$, and grown to $10^{8}$ colony forming units $(\mathrm{CFU}) / \mathrm{mL}$, as determined by their optical density at $625 \mathrm{~nm}$ and verified by both replicate plating on nutrient agar ${ }^{25}$ and the $0.5 \mathrm{McFarland}$ standard. An antibacterial assay was studied using the Kirby Bauer disk diffusion assay on S.A (gram $+v e$ ), P.A. (gram -ve), and E-Coli (gram -ve) ${ }^{26}$. Briefly, bacteria were inoculated in physiological saline ( $0.85 \%$ wt NaCl-Sigma-Aldrich). Sterile swab was used to inoculate isolates over the agar surface, followed by streaking to obtain a bacterial lawn. Next, $5 \mu \mathrm{L}$ of Ag-PMHS nanocomposite was carefully seeded onto a $6 \mathrm{~mm}$ agar disk. Finally, the plates were aerobically incubated at $37^{\circ} \mathrm{C}$ for $24 \mathrm{~h}$ in an incubator. Subsequently, the results were analyzed by measuring the ZOI. Three independent experiments were triplicated. Data were analyzed by a one-way analysis of variance (ANOVA) with the Tukey-Kramer multiple comparison test. Results were considered significant at $\mathrm{p}<0.05$.

Anti-biofouling and biofilm inhibition assay. Bacterial strain was grown overnight to obtain $10^{8}$ $\mathrm{CFU} / \mathrm{mL}$. Anti-biofouling experiment was conducted using a protocol described elsewhere ${ }^{23}$ with minor modifications. Briefly, two staining jars were filled with $99 \mathrm{~mL}$ physiological saline $(0.85 \%$ wt $\mathrm{NaCl}$ ) and $1 \mathrm{~mL}$ bacterial culture. Subsequently, both $2.54 \mathrm{~cm} \times 2.54 \mathrm{~cm}$ anodized $\mathrm{Al}(\mathrm{Al} / \mathrm{AAO}$, used as control) and superhydrophobic AAO/Al sample (04Sil-AgP-NcAAO), were placed in two separate jars. The staining jars were incubated for $3 \mathrm{~h}$ at $37^{\circ} \mathrm{C}$. The substrates were subsequently removed and gently immersed in physiological saline to rinse non-adherent bacteria. Next, the substrates were transferred into a set of $80 \mathrm{~mL}$ sterile beakers containing physiological saline and sonicated on ice for $10 \mathrm{~min}$ to remove adherent bacteria. Finally, the bacterial suspensions were serially diluted and then plated on tryptic soy agar, followed by an aerobic incubation at $37^{\circ} \mathrm{C}$ for 
$24 \mathrm{~h}$. Positive controls were performed for $\mathrm{t}=0$ and $\mathrm{t}=3 \mathrm{~h}$ to ascertain the bacterial viability. Three independent experiments were performed in triplicate to determine the number of adherent bacteria. Relative bacterial adhesion reduction was calculated using the following formula: Relative bacterial adhesion reduction $=[(\mathrm{A}-\mathrm{B}) / \mathrm{A} \times 100 \%]$, where $\mathrm{A}=\mathrm{CFU} / \mathrm{cm}^{2}$ of adherent bacteria on anodized $\mathrm{Al}(\mathrm{AAO} / \mathrm{Al})$ and $\mathrm{B}=\mathrm{CFU} / \mathrm{cm}^{2}$ of adherent bacteria on superhydrophobic AAO/Al sample (04Sil-AgP-NcAAO). Biofilm inhibition study was also performed on E-coli bacterium for $48 \mathrm{~h}$ to evaluate the ability of superhydrophobic AAO/Al sample (04Sil-AgP$\mathrm{NcAAO}$ ) at inhibiting E-coli bacterium colonization. Test culture was diluted with physiological saline $(0.85 \%$ wt. $\mathrm{NaCl})($ Sigma-Aldrich) to achieve a bacterial inoculum concentration of $1.0 \times$ $10^{7}$ colony-forming units/millilitre (CFU) $\mathrm{mL}^{-1}$. Next, $22.5 \mathrm{~mL}$ tryptic soy broth was added to 2.5 $\mathrm{mL}$ bacterial inoculum in separate sterile petri dishes. Both the test sample (04Sil-AgP-NcAAO) and the control sample (AAO/Al ) were then immersed in these petri dishes, followed by $48 \mathrm{~h}$ incubation for biofilm growth. Subsequently, samples were rinsed with the physiological saline, followed by air-drying in airflow Class II cabinet at ambient conditions of $25^{\circ} \mathrm{C}$ and $(50 \pm 10 \%)$ relative humidity $(\mathrm{RH})$ for $1 \mathrm{~h}$. Samples were finally metalized with gold coating and imaged in a high vacuum SEM. Data were analyzed by ANOVA with the Tukey-Kramer multiple comparison test. Results were considered significant at $\mathrm{p}<0.05$.

\section{RESULTS AND DISCUSSION}

Synthesis of Ag-PMHS nanocomposites. PMHS is a linear organofunctional polysiloxane, in which the active moiety, $(\mathrm{Si}-\mathrm{H})$ reacts with metallic salts to form the corresponding metallic 
particles owing to the strong reducing ability of the PMHS ${ }^{19}$. In particular, when silver salts such as $\mathrm{AgNO}_{3}$ react with the PMHS, the $\mathrm{Si}-\mathrm{H}$ bond is oxidized into $\mathrm{Si}-\mathrm{O}-\mathrm{Si}$ species with $\mathrm{H}_{2}$ gas evolution and hydridic hydrogen replaced by Ag-NPs ${ }^{20}$ as seen in Eq. 1.

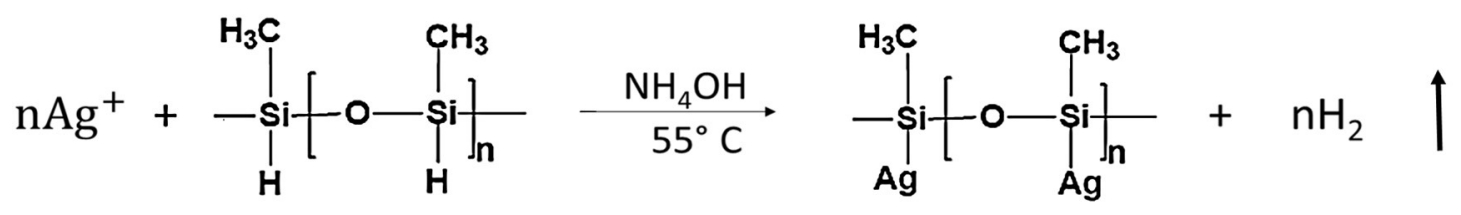

The polymeric PMHS matrix is an ideal template for in-situ Ag-NPs synthesis, similar to the typical host-guest redox reaction ${ }^{19}$. It is noteworthy that such a host-guest structure might exhibit interesting antibacterial properties, in which PMHS acts as a polymeric matrix for holding and presumably triggering controllable $\mathrm{Ag}^{+}$release for killing or inhibiting bacterial growth.

To ascertain the amount of $\mathrm{Ag}^{+}$ions required to react with the active $\mathrm{Si}-\mathrm{H}$ moiety, the $\mathrm{Ag}^{+} / \mathrm{Si}-\mathrm{H}$ molar ratio was varied from 1:50 to 50:1 (Table 1). Figure 1 shows the ATR-FTIR spectra of PMHS before and after reaction with $\mathrm{AgNO}_{3}$ for different molar ratios of $\mathrm{Ag}^{+} / \mathrm{Si}-\mathrm{H}$. Figure 1 (III) shows the ATR-FTIR spectrum of liquid PMHS. The single peak at $2939 \mathrm{~cm}^{-1}$ at the highfrequency region can be assigned to the asymmetric stretching mode of $-\mathrm{CH}_{3}$ groups in the PMHS molecule ${ }^{27}$. At the lower frequency region, the two peaks at 1270 and $764 \mathrm{~cm}^{-1}$ correspond to $\mathrm{Si}-\mathrm{CH}_{3}$ groups ${ }^{28}$. Similarly, the peak at $1100 \mathrm{~cm}^{-1}$ can be linked to the asymmetrical stretching vibration of the $\mathrm{Si}-\mathrm{O}-\mathrm{Si}$ mode ${ }^{29}$, while that around $800 \mathrm{~cm}^{-1}$ can be attributed to the symmetric bending mode of the $\mathrm{Si}-\mathrm{O}-\mathrm{Si}$ bonds ${ }^{30}$. The peak at $2162 \mathrm{~cm}^{-1}$ at the mid-frequency region is assigned to the $\mathrm{Si}-\mathrm{H}$ stretching mode. Notably, at a lower molar ratio of $\mathrm{Ag}^{+} / \mathrm{Si}-\mathrm{H}$, such as 2:50 (Figure 1.(II)), the intensity of the $\mathrm{Si}-\mathrm{H}$ group marginally decreases by $\sim 10 \%$ compared with the 
as-received PMHS, suggesting that less amount of $\mathrm{Si}-\mathrm{H}$ species are consumed. However, at higher molar ratios of $\mathrm{Ag}^{+} / \mathrm{Si}-\mathrm{H}$ such as $50: 2$, the $\mathrm{Si}-\mathrm{H}$ group is no longer observed (Figure 1 (I)), signifying that all the $\mathrm{Si}-\mathrm{H}$ species are consumed. A similar observation was made by Omer $\mathrm{D}$. et al. ${ }^{20}$, however, their $\mathrm{Si}-\mathrm{H}$ peak intensity at a higher $\mathrm{Ag}^{+} / \mathrm{Si}-\mathrm{H}$ molar ratio $(1: 1)$ decreased by 90 $\%$ compared with ours of $100 \%$, owing to the total consumption of the $\mathrm{Si}-\mathrm{H}$ species in our case. Our high $\mathrm{Ag}^{+} / \mathrm{Si}-\mathrm{H}$ molar ratio was necessary due to the intended antibacterial application.

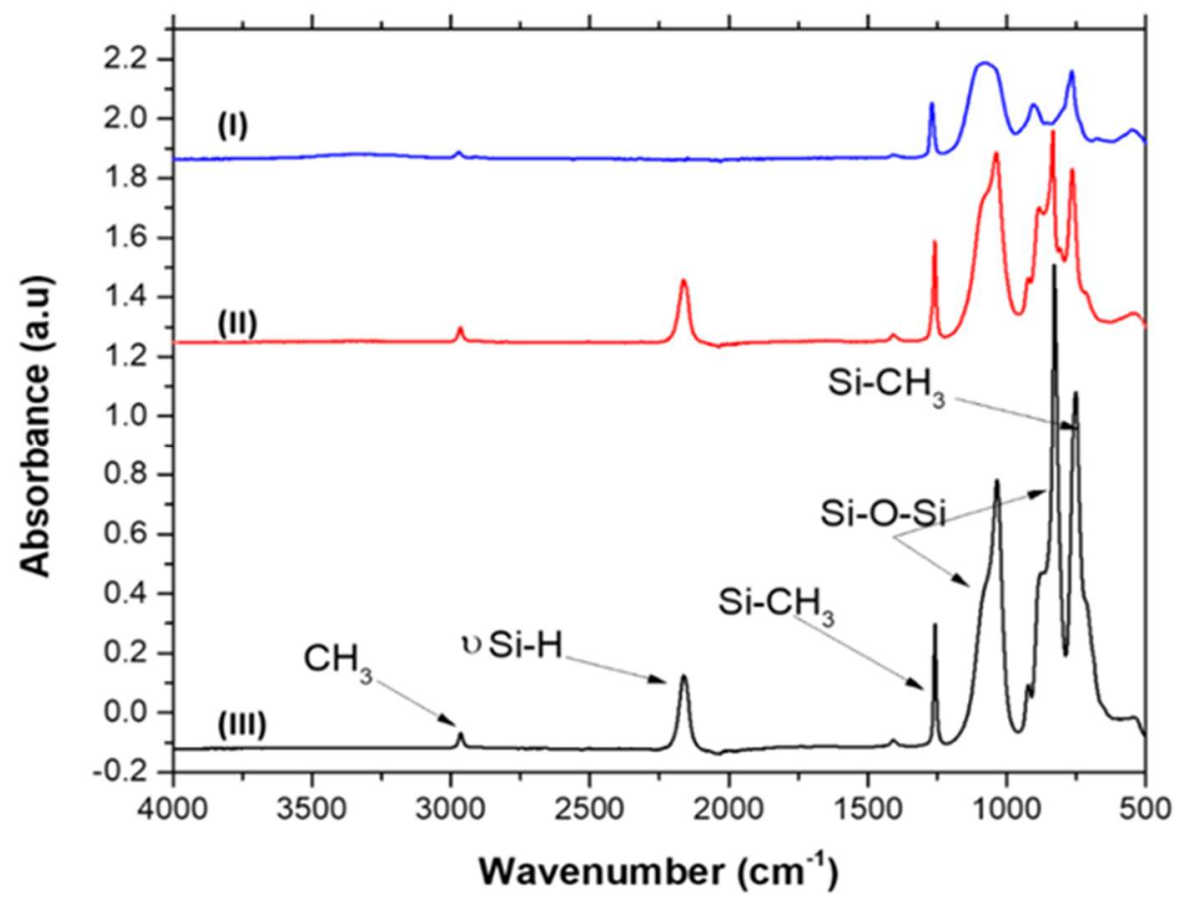

Figure 1. ATR-FTIR spectra of PMHS before and after reaction with $\mathrm{AgNO}_{3}$ at different mole ratios: (I) $\left(\mathrm{Ag}^{+} / \mathrm{Si}-\mathrm{H}\right.$ of $\left.50: 2\right)$; (II) $\left(\mathrm{Ag}^{+} / \mathrm{Si}-\mathrm{H}\right.$ of $\left.2: 50\right)$; and (III) liquid PMHS

In addition to $\mathrm{Ag}$, other metal nanoparticles, such as those of $\mathrm{Au}, \mathrm{Pt}, \mathrm{Ta}$, and $\mathrm{Nb}$ can be synthesized by PMHS ${ }^{31}$. In fact, the active $\mathrm{Si}-\mathrm{H}$ moiety arranged periodically on the siloxane backbone in the 
PMHS matrix, provides intrinsic sites to synthesize and integrate these metal nanoclusters ${ }^{20}$. AgPMHS nanocomposites exhibit a surface plasmonic resonance phenomenon, which is similar to other chemical reduction syntheses of Ag-NPs. This surface plasmon resonance is due to the collective oscillation of conducting electrons of Ag-NPs, characteristically observed by a color change in Ag-PMHS solutions. Notably, when $\mathrm{AgNO}_{3}$ is added to the PMHS gel, a redox reaction begins immediately with a color change from colorless to yellow, orange, brown, and black (nucleation, nanoparticles, nanoclusters, and growth of controlled aggregates, respectively), as well as, the corresponding formation of different Ag species ${ }^{20}$. In fact, it has been reported that using $\mathrm{NH}_{3}$ (aq) as a catalyst, $\mathrm{Si}^{\delta+}-\mathrm{H}^{\delta-}$ bonds are polarized via the intermediate formation of hypercoordinated silicon species to increase the sol-gel reaction rate ${ }^{32}$. At the gel point (achieved after $24 \mathrm{~h}$ ), a viscous, stable and elastic gel network was observed. Note that typical sol-gel process without $\mathrm{NH}_{3}$ (aq) can last for $\sim 1000 \mathrm{~h}^{33}$. In deed, the $\mathrm{NH}_{3}$ (aq) does not only catalyze the hydrolysis process but also forms a complex ion with $\mathrm{Ag}^{+}\left(\mathrm{Ag}\left(\mathrm{NH}_{3}\right)_{2}{ }^{+}\right.$aq) to accelerate the reduction of $\mathrm{Ag}^{+}$ ions by PMHS. This is similar to saccharides reduction of $\mathrm{Ag}^{+}$ions (in the presence of $\mathrm{NH}_{3}(\mathrm{aq})$ ) in a typical modified Tollens Ag synthesis ${ }^{34-35}$. However, for the purpose of obtaining a thin AgPMHS nanocomposite coating on $\mathrm{AAO} / \mathrm{Al}$, the ageing process was limited to $30 \mathrm{~min}$ in our experiment.

Figure 2 (A) shows the energy dispersive X-ray spectroscopy (EDS) spectrum of elements in the $\mathrm{Ag}-\mathrm{PMHS}$ nanocomposite $(\mathrm{Ag}+/ \mathrm{Si}-\mathrm{H}$ of 50:2 mole ratio), which comprises $\mathrm{C}, \mathrm{O}$, and $\mathrm{Si}$ with their respective $\mathrm{K}_{\alpha}$ peaks at $0.28,0.52$, and $1.73 \mathrm{keV}$ respectively, and an $\mathrm{L}_{\alpha}$ peak of $\mathrm{Ag}$ at 2.98 $\mathrm{keV}$. Similarly, the XRD pattern is shown in Figure 2 (B). The XRD pattern matched well with the JCPDS card (89-3722) standard data of Ag, characterized by a face-centered cubic crystalline 
silver, with corresponding prominent peaks for $2 \theta$ at $38.17^{\circ}, 44.31^{\circ}$, and $64.44^{\circ}$. Both the EDS and XRD spectra confirm the formation of Ag-NPs in the PMHS siloxane polymer.
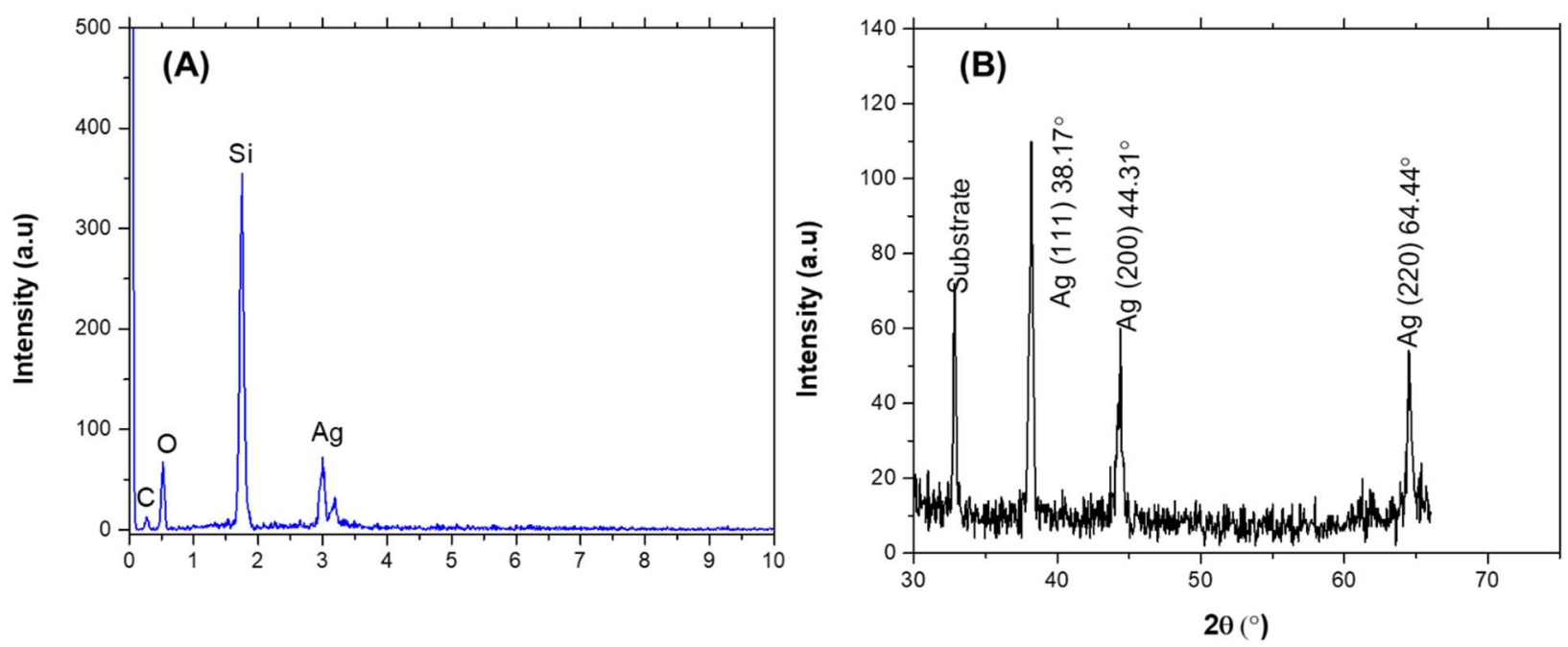

Figure 2. (A) EDS spectrum and (B) XRD pattern of as-synthesized Ag-PMHS nanocomposite having a $\mathrm{Ag}^{+} / \mathrm{Si}-\mathrm{H}$ molar ratio of 50:2.

Anodization. In the present study, anodization was performed to engineer an Al substrate to achieve a high surface topography for coating the Ag-PMHS nanocomposite. Anodization is ideal because it is technologically scalable and offers abrasion and corrosion resistance ${ }^{36}$. In a typical galvanostatic anodization process, potential increases linearly with anodization time ${ }^{37}$. The process begins with nucleation and the subsequent growth of porous structures (Figure $3(\mathrm{~A})$ ). As oxide dissolution begins, porous structures are formed. Finally, a steady state of oxide dissolution and formation equilibrium is attained. Notably, for the 120 min sample, the potential increased linearly with time, and beyond the critical voltage (49 V) after $60 \mathrm{~min}$ of anodization (Figure 3 (B)). This rise was due to the high resistance of the oxide barrier layer. Beyond the critical voltage, the potential decreased marginally (a decrease of $\sim 4 \mathrm{~V}$ ) with anodization time, until the rate of oxide dissolution was equivalent to the rate of porous oxide layer formation ${ }^{38}$. However, for both 
the $60 \mathrm{~min}$ and $30 \mathrm{~min}$ samples, incomplete anodization was observed. Hence, the $120 \mathrm{~min}$ anodized sample was selected for the remainder of the study.

(A)

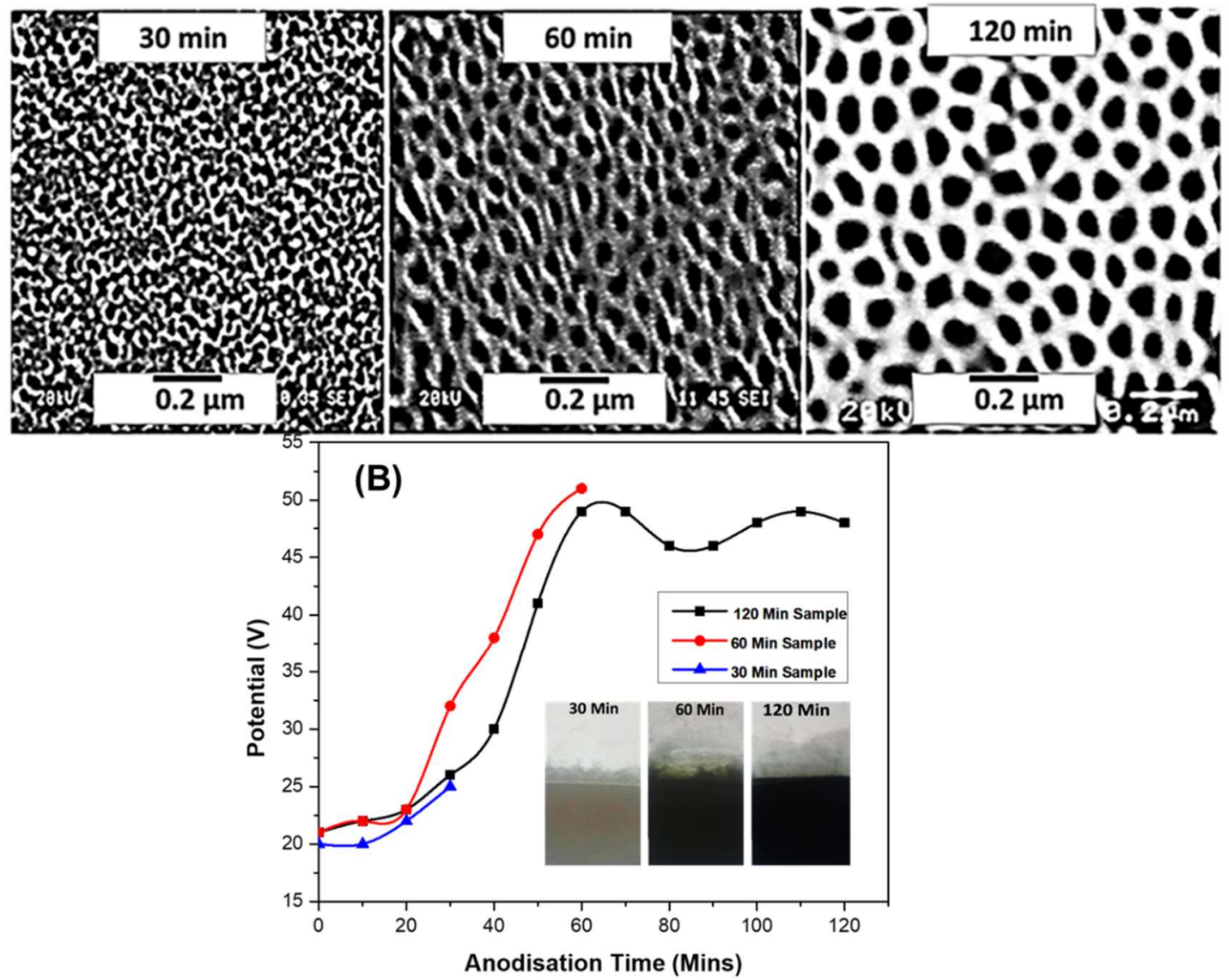

Figure 3 (A) SEM image of anodized aluminum oxide (AAO) after a $30 \mathrm{~min}$ anodization (left); 60 min (middle); and 120 min (right): (B) kinetics of anodization process for the three samples above (where $120 \mathrm{~min}$; $60 \mathrm{~min}$; and A 30 min). Inset: Digital image of the three samples.

To engineer a superhydrophobic Ag-PMHS nanocomposite coating on Al with inherent antibacterial property, the $\mathrm{Ag}-\mathrm{PMHS}$ nanocomposite with a $\mathrm{Ag}^{+} / \mathrm{Si}-\mathrm{H}$ molar ratio of 50:2 was coated on the 120 min anodized $\mathrm{Al}$ (herein referred to as $\mathrm{AgP}-\mathrm{NcAAO}$ ) and used for the 
remainder of the study. Both the XRD (Figure 4 (A)) and EDS spectra (Figure 4 (B)) show that the chemical composition of the fabricated $\mathrm{AgP}-\mathrm{NcAAO}$ sample comprises $\mathrm{Al}$ and $\mathrm{O}$; and $\mathrm{Ag}, \mathrm{Si}$, and $\mathrm{C}$; from $\mathrm{Al}_{2} \mathrm{O}_{3}$ (owing to anodization) and the $\mathrm{Ag}-\mathrm{PMHS}$ nanocomposites, respectively. The broad peak at $10.0^{\circ}$ is typical for amorphous $\mathrm{SiO}_{2}{ }^{39}$, which arises from the reaction of PMHS with $\mathrm{AgNO}_{3}$. Notably, the Al peaks ((111), (200), (220), and (311) from the underlying $\mathrm{Al}$ substrate), overlap with the Ag peaks ((111), (200), (220), and (311)). The overlapping of diffraction peaks of $\mathrm{Al}$ (111) and $\mathrm{Ag}$ (111) is due to their similar lattice parameters (Figure 4 (A), inset). The presence of sulfur in the EDS spectra of Figure 4 (B) can be ascribed to sulfuric acid from anodization. It is noteworthy that an optimal wt.\% RTV silicone was used to improve the adhesive bonding of the $\mathrm{AgP}-\mathrm{NcAAO}$ sample (herein referred to as $04 \mathrm{Sil}-\mathrm{AgP}-\mathrm{NcAAO}$ ) (Figure 4 (B (III)).
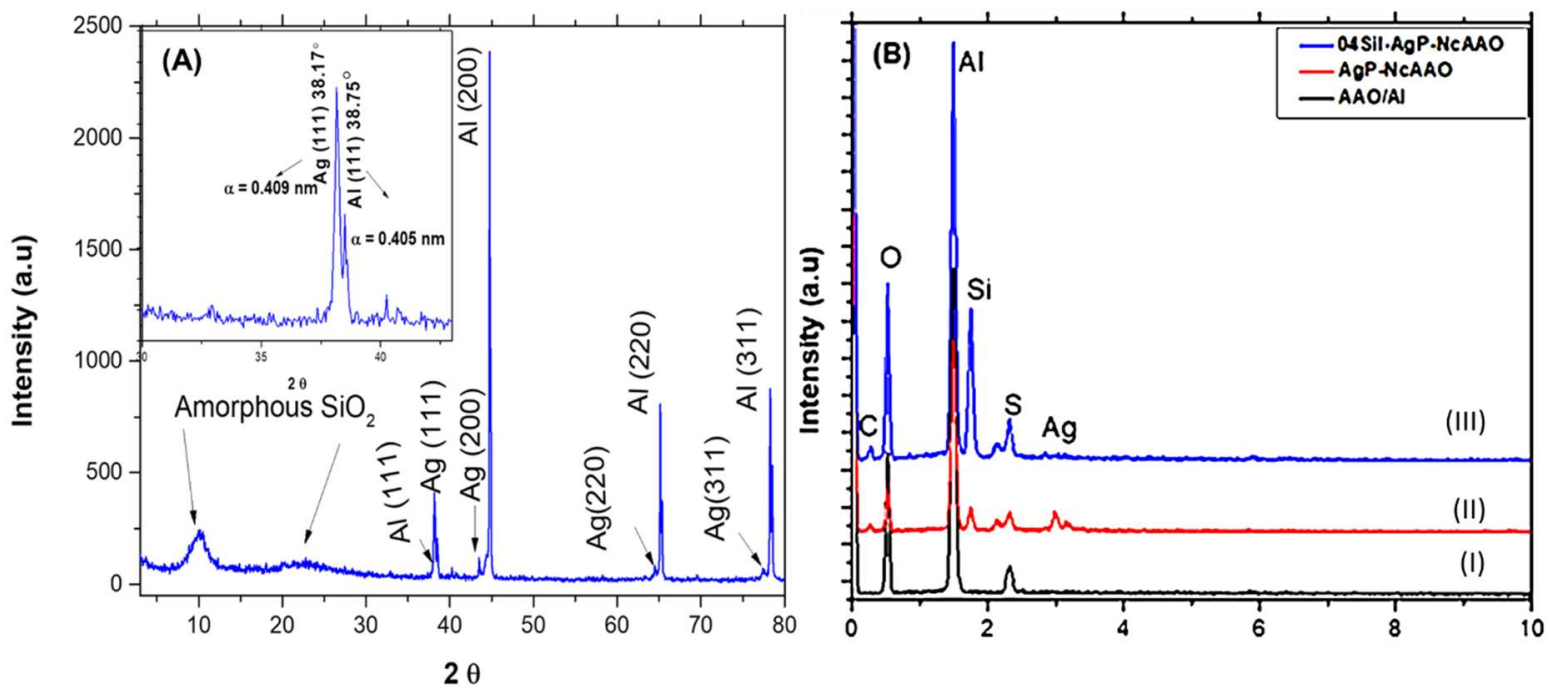

Figure 4: (A) XRD pattern of Ag-PMHS nanocomposite having a $\mathrm{Ag}^{+} / \mathrm{Si}-\mathrm{H}$ molar ratio of 50:2.0 coated on $\mathrm{AAO} / \mathrm{Al}(\mathrm{AgP}-\mathrm{NcAAO})$; (B) EDS spectra of : (I) $\mathrm{AAO} / \mathrm{Al}$; (II) AgP-NcAAO; (III) $0.4 \%$ w/v silicone incorporated in AgP-NcAAO 
(04Sil-AgP-NcAAO). (Inset: high magnification of Ag and Al (111) planes with their lattice parameters).

Superhydrophobic property. The two well-known conditions for fabricating superhydrophobic surfaces are the combined effects of low surface energy and geometrical surface structure ${ }^{40}$. In the present study, the desired topography was achieved through the combined effects of Al anodization and presence of silver nanoparticles (Ag-NPs), while low surface energy, by passivation with PMHS molecules. Though, two-step anodization process produces self-organised densely hexagonal AAO templates ${ }^{41}$, the process is somehow complex and time consuming, hence we have deployed a one-step constant current hard anodisation process to achieve desired surface topography. The surface roughness and CA of the as-received Al substrate were $0.4 \pm 0.02 \mu \mathrm{m}$ and $94 \pm 1.2^{\circ}$, respectively. CA of $113 \pm 1.5^{\circ}$ was observed for the Ag-PMHS nanocomposite coating on this surface (as shown in supplementary information, Table S1). Table 2 and Figure 5 provide information regarding the surface roughness and SEM micrograph. After a 120 min anodization, uniformly distributed nanopores of average pore diameter and cell diameter $60 \pm 11 \mathrm{~nm}$ and 121 $\pm 19 \mathrm{~nm}$, respectively, were observed (Table 3). The surface roughness and CA of $9.1 \pm 0.9 \mu \mathrm{m}$ and $8 \pm 0.2^{\circ}$, respectively, were obtained for $120 \mathrm{~min}$ AAO (Figure $5 \mathrm{~B}$ ). This shows that anodization affected the superhydrophilic property on the Al alloy surface. According to the Wenzel model ${ }^{42}$, this is due to the increase wettability of the anodized surface. By contrast, the surface roughness of $9.7 \pm 1.0 \mu \mathrm{m}$ and $\mathrm{CA}$ of $159 \pm 1.2^{\circ}$ were achieved for the Ag-PMHS nanocomposite coating on the 120 min AAO sample (AgP-NcAAO) (Figure $5 \mathrm{C}$ ). The combined effects of the low surface energy PMHS and the empty space by micro-nanostructures, induced by both Ag-cluster and AAO lead to superhydrophobicity that can be explaind by Cassie-Baxter 
$\operatorname{model}^{43}$. The change in surface wettability from superhydrophilic to superhydrophobic can be attributed to both the nano-micro surface roughness (induced by both Ag-NPs and anodization) and the presence of low surface-energy organosilicon (long $\mathrm{Si}-\mathrm{CH}_{3}$ chain). The presence of AgNPs, presumably increase the nano-micro roughness of the Ag-PMHS nanocomposite . We have observed a linear relationship between the CA of the coatings on AAO and Ag:PMHS molar ratio (supplementary information can be found in Table S1, describing contact angle measurements of Ag-PMHS nanocomposites at different molar ratio on Al substrates). However, in the absence of Ag-NPs, a lower CA of $123 \pm 3.1^{\circ}$ was obtained for PMHS coated on AAO. Indeed, we have shown in our previous contribution that a high water CA $\left(\sim 152^{\circ}\right)$ could only be achieved after appropriate combination of PMHS molecule and nano-micro roughness, induced by colloidal $\mathrm{TiO}_{2}$ $\mathrm{NPs}^{28}$. To improve the adhesive property of the AgP-NcAAO sample, RTV-silicone, a well-known adhesive and hydrophobic silicone copolymer with water $\mathrm{CA}<120^{\circ}{ }^{44}$, was loaded into the $\mathrm{Ag}-$ PMHS nanocomposites. Consequently, the CA increased to above $150^{\circ}$ (Figure $5 \mathrm{D}$ ).

Table 2. The surface topography of samples

\begin{tabular}{lc}
\hline Samples & Surface Roughness $(\mathrm{rms}) / \mu \mathrm{m}$ \\
\hline As-received Al Alloy & $0.4 \pm 0.02$ \\
120 min AAO & $9.1 \pm 0.9$ \\
AgP-NcAAO & $9.7 \pm 1.0$ \\
04Sil-AgP-NcAAO & $8.9 \pm 2.0$ \\
\hline
\end{tabular}

Table 3 : Morphological features of anodized samples at varied anodization time 


\begin{tabular}{ccccccc}
\hline Samples & Pore Diameter: & Cell Diameter: & Wall Thickness: & Oxide Thickness & Pore Density: & Porosity: \\
& $\mathrm{D}_{\mathrm{p}}(\mathrm{nm})$ & $\mathrm{D}_{\mathrm{c}}(\mathrm{nm})$ & $\mathrm{W}(\mathrm{nm})$ & $(\mu \mathrm{m})$ & $\mathrm{n}\left(\right.$ Pore $\left./ \mathrm{cm}^{2}\right)$ & $\alpha(\%)$ \\
\hline $120 \mathrm{~min}$ & $60 \pm 11$ & $121 \pm 19$ & $31 \pm 4$ & $75 \pm 2.0$ & $7.9 \times 10^{9}$ & 22 \\
\hline $60 \mathrm{~min}$ & $39 \pm 18$ & $90 \pm 20$ & $26 \pm 2$ & $56 \pm 1.0$ & $1.4 \times 10^{10}$ & 39 \\
$30 \mathrm{~min}$ & $26 \pm 6$ & $59 \pm 14$ & $17 \pm 4$ & $36 \pm 0.7$ & $3.3 \times 10^{10}$ & 40 \\
\hline
\end{tabular}
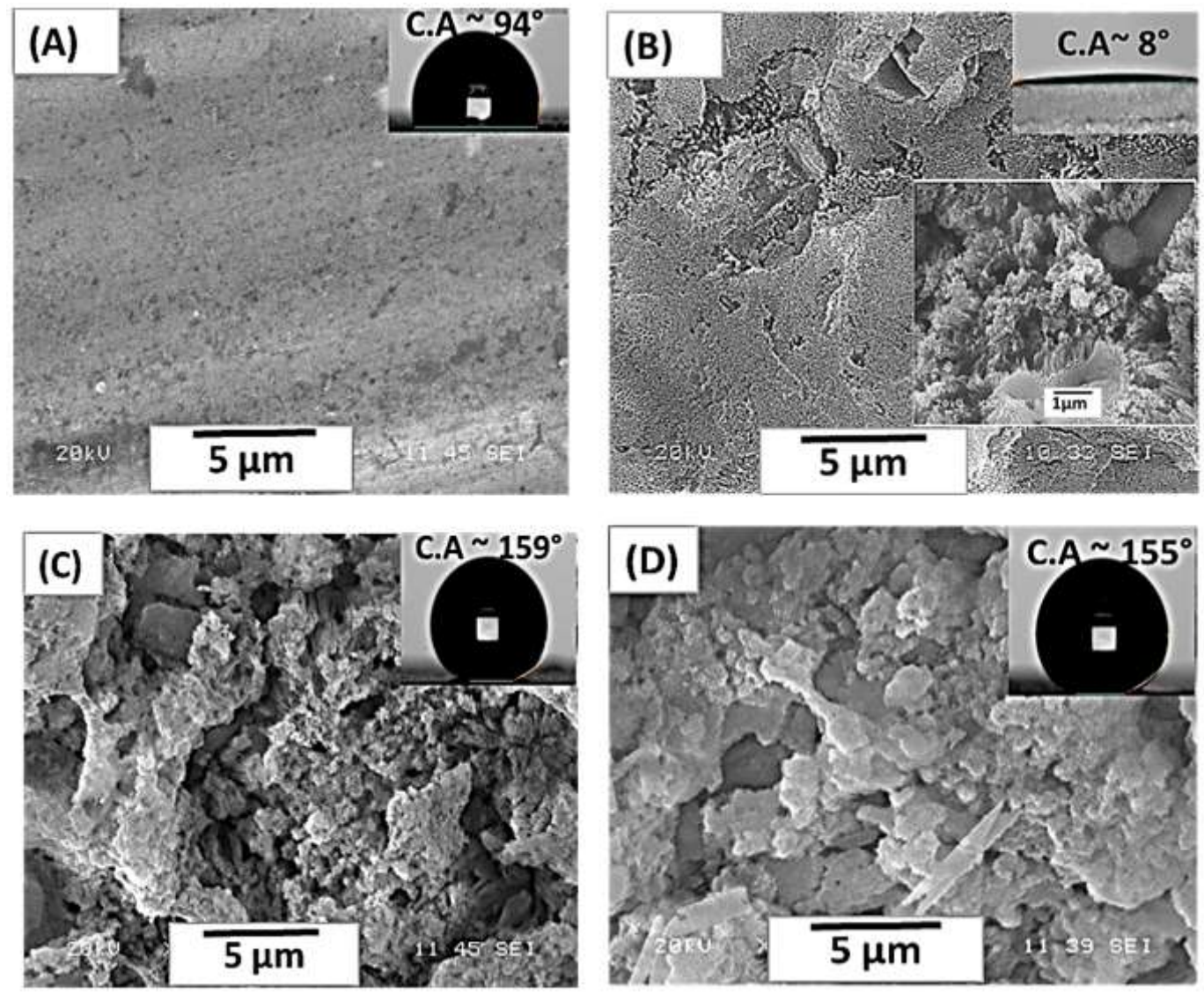

Figure 5. SEM images of (A) as-received $\mathrm{Al}$; (B) $\mathrm{AAO} / \mathrm{Al}$; (C) $\mathrm{Ag}-\mathrm{PMHS}$ nanocomposite having a $\mathrm{Ag}^{+} / \mathrm{Si}-\mathrm{H}$ molar ratio of $50: 2$ coated on $\mathrm{AAO} / \mathrm{Al}(\mathrm{AgP}-$ 
$\mathrm{NcAAO}$ ); (D) $0.4 \%$ w/v silicone incorporated in $\mathrm{AgP}-\mathrm{NcAAO}$ (04Sil-AgP-NcAAO);

The insets show $5 \mu \mathrm{L}$ water drops deposited on the surface along with 1 and $5 \mu \mathrm{m}$ scale bars

In particular, we observed that after silicone loading, the CA increased from $8 \pm 0.2^{\circ}$ for $120 \mathrm{~min}$ $\mathrm{AAO}$, to $155 \pm 0.4^{\circ}$ for $04 \mathrm{Sil}-\mathrm{AgP}-\mathrm{NcAAO}$. Interestingly, increasing the silicone wt. $\%$ resulted in an $8^{\circ}$ decrease in CA (Figure. 6). This trend is similar to our previous observation when silicone wt.\% was deposited on etched $\mathrm{Al}^{45}$. The decrease in $\mathrm{CA}$ following the continuous silicone loading can be attributed to the filling-in of the AAO micro- and nanostructures, which results in the smoothening the rough surface. However, the AgP-NcAAO sample resulted in a higher surface roughness of $9.7 \pm 1.0 \mu \mathrm{m}$ and $\mathrm{CA}$ of $159 \pm 0.5^{\circ}$, compared with surface roughness of $8.9 \pm 2.0$ $\mu \mathrm{m}$ and $\mathrm{CA}$ of $155 \pm 0.4^{\circ}$, for the $04 \mathrm{Sil}-\mathrm{AgP}-\mathrm{NcAAO}$ sample. It must be re-emphasized that the high $\mathrm{CA}$ value for the $\mathrm{AgP}-\mathrm{NcAAO}$, relative to $04 \mathrm{Sil}-\mathrm{AgP}-\mathrm{NcAAO}$, is attributed to the partial filling of the entrapped air in the micro-nanoporous structures by RTV-silicone, in accordance with the Cassie-Baxter model ${ }^{43}$.

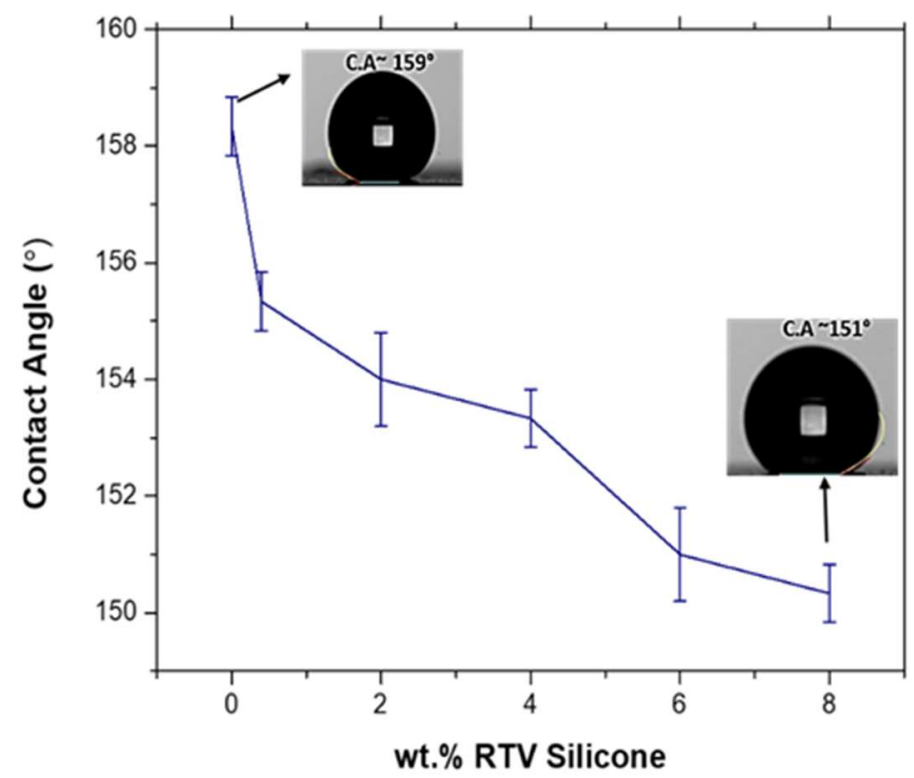


Figure 6. Water contact angle on the surface of Ag-PMHS nanocomposites having a $\mathrm{Ag}^{+} / \mathrm{Si}-\mathrm{H}$ molar ratio of 50:2 as a function of wt.\% of incorporated silicone.

According to the Cassie-Baxter model, a rough surface would repel liquid droplets owing to the entrapped air in the nano- and/or microstructural features ${ }^{43}$. The anodization of $\mathrm{Al}$, results in the formation of porous nano- and/or microstructural $\mathrm{Al}_{2} \mathrm{O}_{3}$ features. The $\mathrm{OH}$ group in $\mathrm{Al}_{2} \mathrm{O}_{3}$ can form a strong monodentate or bidentate bonding with the $\mathrm{Si}-\mathrm{O}-\mathrm{Si}$ group of $\mathrm{Ag}-\mathrm{PMHS}$. In particular, the silanol molecule replaces the $\mathrm{OH}$ group, resulting in the formation of water molecules and a strong a $\mathrm{SiO}-\mathrm{Al}$ monodentate bonding on the $\mathrm{Al}_{2} \mathrm{O}_{3}$ surface $^{46}$. Such a strong chemical bonding, coupled with AAO's ability to mechanically anchor PMHS, can increase the adhesion bonding of PMHS coatings.

Note that $0.4 \%(\mathrm{w} / \mathrm{v})$ silicone was deemed optimal for adhesive bonding studies. A test was performed using the American Standard Test Method (ASTM D 3359-02) on four samples (Figure 7 and supplementary information, Table S2 A-D, show grade of adhesive bonding on tested samples). The Ag-PMHS nanocomposite coating on the as- received Al, exhibited the lowest grade of $0 \mathrm{~B}$, while the Ag-PMHS nanocomposite coating on AAO exhibited grades between 4B and 5B. Interestingly, after 90 days of saline immersion, the Ag-PMHS nanocomposite coating on AAO was still resistant to scratch (supplementary information can be found in Table $\mathrm{S} 2 \mathrm{D}$, showing grade of adhesive bonding of Ag-PMHS nanocomposite coating on AAO after 90 days of saline immersion). According to ASTM D3359-02, coatings with 5B grade exhibit the highest adhesion bonding, whereas those with 
grade $0 \mathrm{~B}$ exhibit the lowest adhesion ${ }^{47}$. Notably, anodization provides an optimal surface topography that affords high abrasive resistance to Ag-PMHS nanocomposite coating. The high adhesive bonding observed can be attributed to both chemical and physical phenomena. Chemically, the RTV-silicone increases the monodentate bonding of the $\mathrm{Si}-\mathrm{O}-\mathrm{Si}$ group and the $\mathrm{Al}_{2} \mathrm{O}_{3}$. This is confirmed by the increased intensity of siloxane groups in the FTIR peaks of the 04Sil-AgP-NcAAO (as shown in supplementary information, figure $\mathrm{S} 1(\mathrm{I})$ ). Physically, anodization provides additional support for anchoring the Ag-PMHS nanocomposite coating. In fact, the 04Sil-AgP-NcAAO sample maintains the superhydrophobic property (More details can be found in Video S1, as a movie demonstration of water roll-off property of the superhydrophobic surface) albeit with a $4^{\circ}$ decrease in CA with increased adhesion bonding; therefore, it is ideal for practical applications.

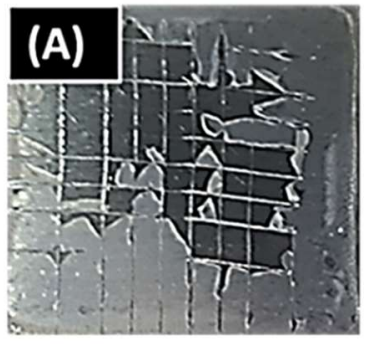

Ag-PMHS nanocomposite coated Al

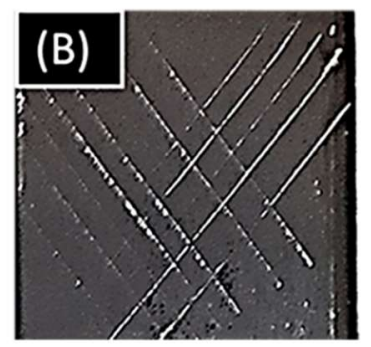

AgP-NcAAO

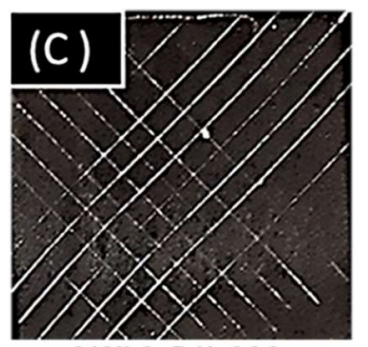

04Sil-AgP-NcAAO

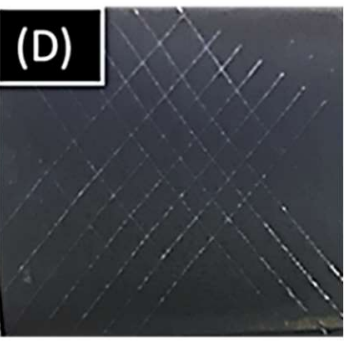

04Sil-AgP-NcAAO-90D

Figure 7. Digital images of scratch test based on American Standard Test Method (ASTM D 3359-02) showing the adhesion of Ag-PMHS nanocomposite coatings having a $\mathrm{Ag}^{+} / \mathrm{Si}-\mathrm{H}$ molar ratio of 50:2 on: (A) as-received $\mathrm{Al}$; (B) $\mathrm{AAO} / \mathrm{Al}(\mathrm{AgP}-\mathrm{NcAAO}) ;(\mathrm{C}) 0.4 \% \mathrm{w} / \mathrm{v}$ silicone incorporated in $\mathrm{AgP}-\mathrm{NcAAO}$ (04Sil-AgP-NcAAO); and (D) 04Sil-AgP-NcAAO in 90 days of immersion (04Sil-AgP-NcAAO-90D). 
Because the chemical nature of the Ag-NPs' surface is crucial for $\mathrm{Ag}^{+}$release kinetics, a representative portion of the superhydrophobic $\mathrm{AAO} / \mathrm{Al}$ sample (04Sil-AgP-NcAAO) was examined through EDS analysis for elemental mapping. Among three different locations of the elemental mapping, Figure 8 (A) shows the SEM micrograph of the representative sites, while Figures 8 (B, C, and D) show the elemental mapping of Ag, Al, and Si, respectively. Dispersed $\mathrm{Ag}$ is distributed on the entire area, as shown in Figure 8 (B). However, clusters of Ag are visible, as marked in the same figure. Conversely, $\mathrm{Al}$ surrounds $\mathrm{Ag}$ (dark region) in the $\mathrm{Al}$ mapping, as shown in Figure 8 (C). Figure 8 (D) shows that $\mathrm{Si}$, from the PMHS molecules, is distributed uniformly across the entire sample. Therefore, the elemental mapping demonstrates that elemental $\mathrm{Ag}$ is distributed over the entire range of the randomly selected area. 

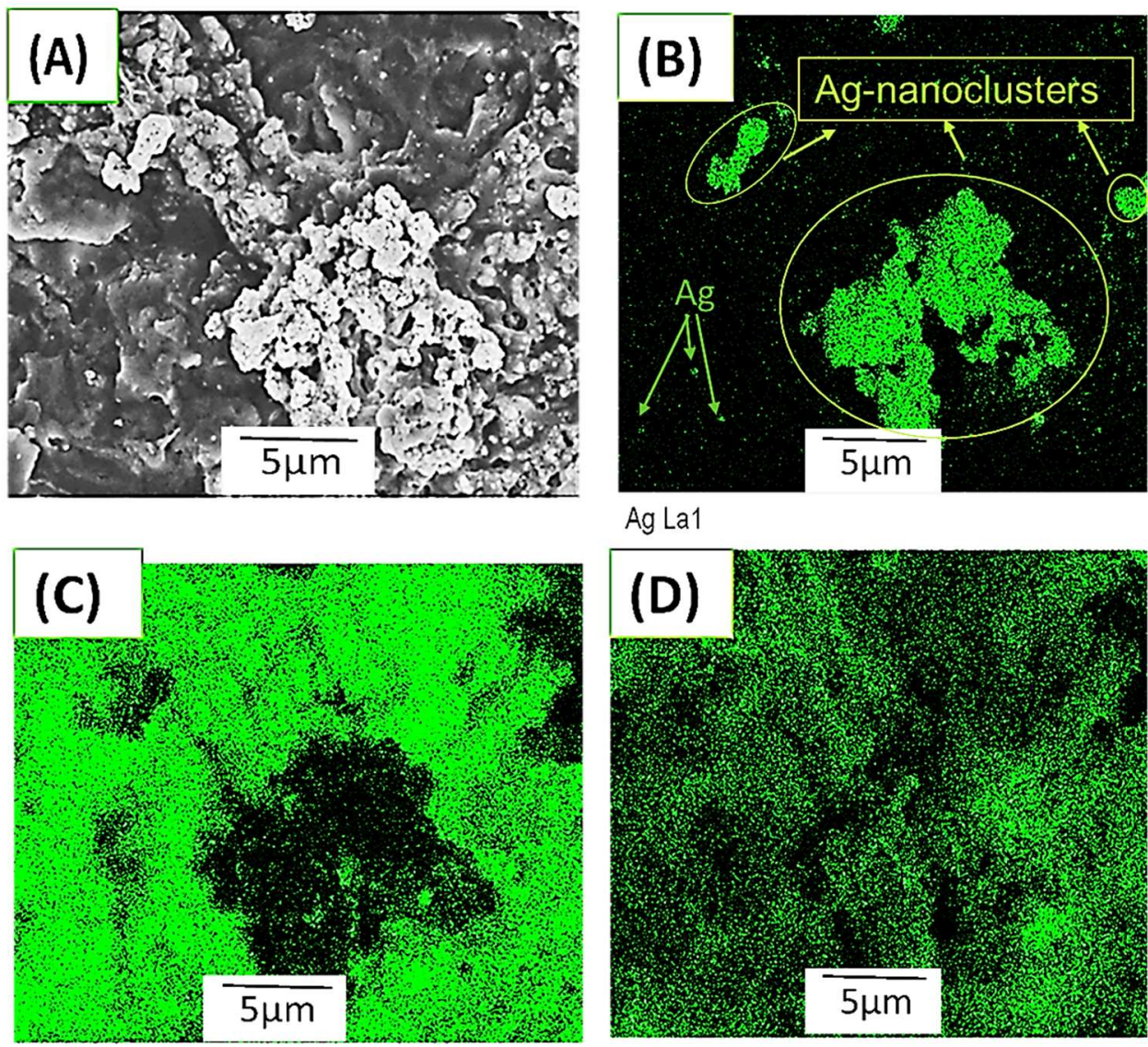

Ag La1

Al Ka1

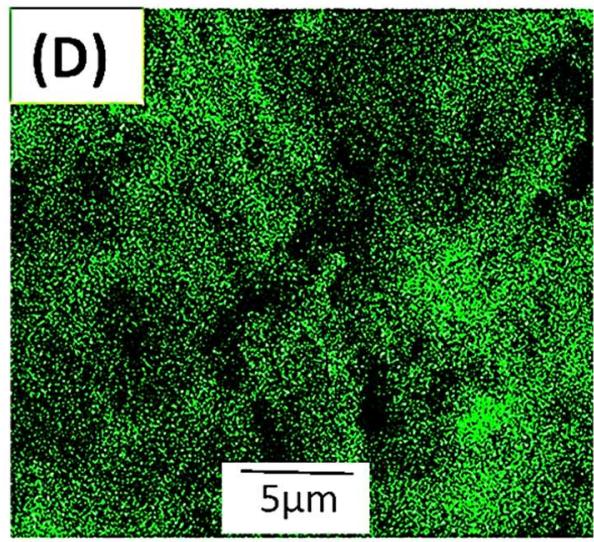

Si Ka1

Figure 8. EDS mapping of $0.4 \% \mathrm{w} / \mathrm{v}$ silicone incorporated in Ag-PMHS nanocomposites having a $\mathrm{Ag}^{+} / \mathrm{Si}-\mathrm{H}$ molar ratio of $50: 2$ coated on $\mathrm{AAO} / \mathrm{Al}(04 \mathrm{Sil}-$ AgP-NcAAO); (A) SEM image (B) Silver; (C) Al; and (D) Silicon.

Bacterial susceptibility study. Antibacterial study was performed using two methods. First, antibacterial activity of the Ag-PMHS nanocomposites by the Kirby Bauer disk diffusion assay; second, anti-biofouling study. As model microbes, S.A, P.A, and E-coli were used. It is noteworthy that these bacteria are among the 12 families of the most dangerous antibiotic-resistant bacteria or "superbugs," of clinical significance ${ }^{48}$. The Kirby Bauer assay utilizes the ZOI to describe regions 
around the antimicrobial agent, where bacteria colony or growth is inhibited owing to the former's ability to diffuse. Figure 9 shows the results of the disk diffusion assay.

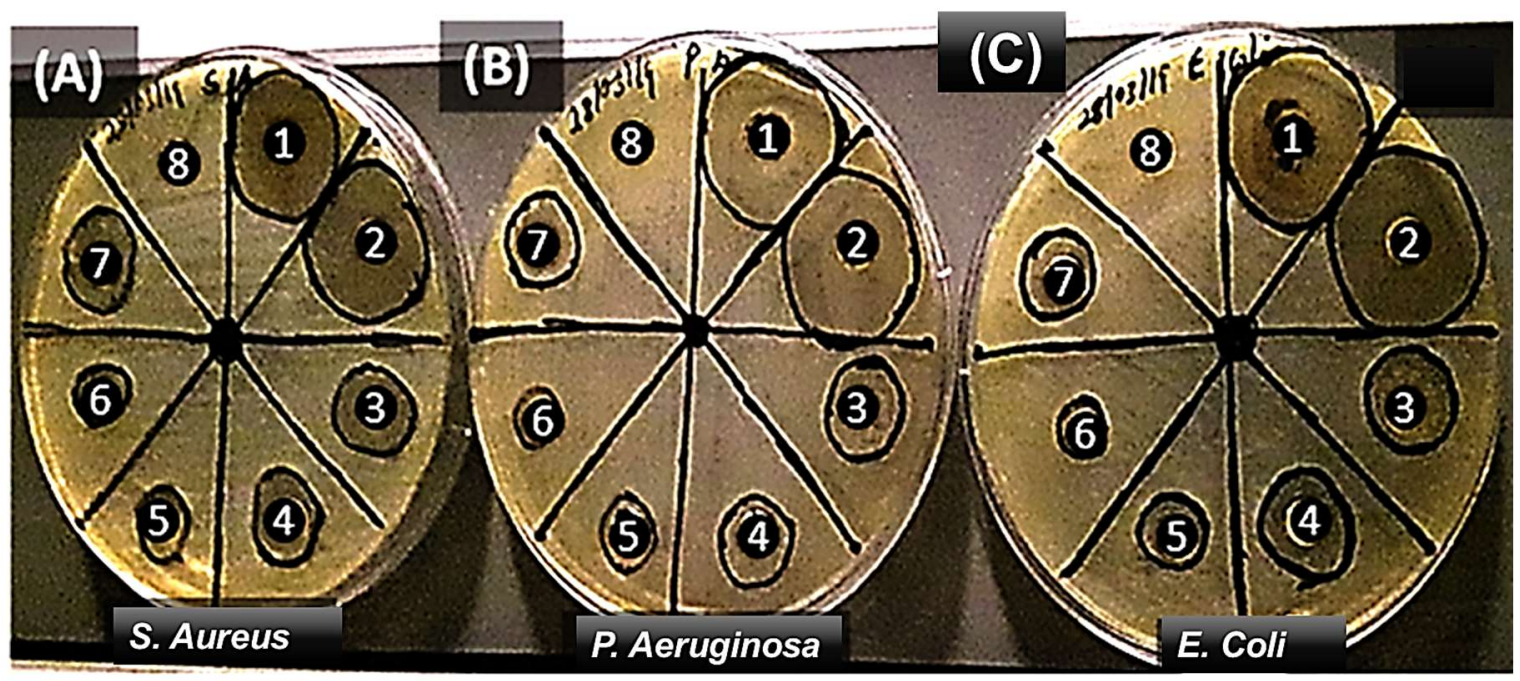

Figure 9. Antibacterial activity of Ag-PMHS nanocomposites against: (A) Staphylococcus aureus (S.Aureus); (B) Pseudomonas aeruginosa (P.Aeruginosa); and (C) Escherichia coli (E-coli). Region $1(\mathrm{Ag}+/ \mathrm{Si}-\mathrm{H}$ of 50:1); region $2(\mathrm{Ag}+/ \mathrm{Si}-\mathrm{H}$ of 50:2); region $3(\mathrm{Ag}+/ \mathrm{Si}-\mathrm{H}$ of $50: 30)$; region $4(\mathrm{Ag}+/ \mathrm{Si}-\mathrm{H}$ of $50: 40)$; region 5 $(\mathrm{Ag}+/ \mathrm{Si}-\mathrm{H}$ of $50: 50)$; region $6(\mathrm{Ag}+/ \mathrm{Si}-\mathrm{H}$ of $2: 50)$; region $7(\mathrm{Ag}+/ \mathrm{Si}-\mathrm{H}$ of $1: 50)$; region 8 represents the Control (mineral spirit + PMHS) (Disk diffusion assay, represents three independent experiments.

Notably, the $\mathrm{Ag}^{+} / \mathrm{Si}-\mathrm{H}$ molar ratio of 50:2 was the most effective, followed by $50: 1$, and the least being 2:50. The relatively high ZOI value for the $\mathrm{Ag}^{+} / \mathrm{Si}-\mathrm{H}$ molar ratio (1:50), may be due to the antibacterial and anti-biofouling synergistic effect. The mean and standard deviation values of the ZOI for S.A, P.A, and E-coli are $23.3 \pm 3.6,25.3 \pm 0.5$, and $24.8 \pm 0.5 \mathrm{~mm}$, respectively. These ZOI values are well within the acceptable range $(8-30 \mathrm{~mm})$ for standard antibiotics against S.A, 
P.A, and E-coli, per the Clinical and Laboratory Standards Institute standards ${ }^{49}$. This shows that the $\mathrm{Ag}-\mathrm{PMHS}$ nanocomposite at a higher $\mathrm{Ag}^{+} / \mathrm{Si}-\mathrm{H}$ molar ratio such as $50: 2$, is an effective antibacterial agent, particularly for gram negative bacteria compared with the gram-positive bacterium S.A. However, at a lower $\mathrm{Ag}^{+} / \mathrm{Si}-\mathrm{H}$ molar ratio such as 2:50, the $\mathrm{Ag}-\mathrm{PMHS}$ nanocomposite was less effective at inhibiting all the bacteria, with ZOI values of $9.0 \pm 0.8,8.5 \pm$ 0.6 , and $6.8 \pm 0.5 \mathrm{~mm}$ for S.A (gram +ve), P.A (gram - ve), and E-coli (gram -ve), respectively (Figure 10). This can be explained by the fact that as Ag-NPs are locked up at the $\mathrm{Si}-\mathrm{H}$ reducing sites (Eq. 1), less $\mathrm{Ag}^{+}$ions effectively leach out to interact with bacteria to induce their lethal effects. Contrarily, at higher molar ratios of $\mathrm{Ag}^{+} / \mathrm{Si}-\mathrm{H}$ such as 50:2, excess amounts of Ag-NPs are available to leach out a high amount of $\mathrm{Ag}^{+}$ions to induce an increased antibacterial effect. The difference in bioactivity between the two classes of bacteria (gram-ve and gram+ve) may be ascribed to the difference in their cell wall composition and structure. Gram (+ve) bacteria have a thicker peptidoglycan layer composed of short peptides along with a linear polysaccharide chain cross-linking network. This rigid structure inhibits the penetration of Ag-NPs. By contrast, gram (-ve) bacteria have a relatively thinner peptidoglycan layer, overlaid with an outer lipid cell membrane.

Although the antibacterial mechanism of Ag-NPs is still a scientific debate, the generally held view is that, upon bacterial/Ag-NPs contact, $\mathrm{Ag}$-NPs are oxidized into $\mathrm{Ag}^{+}$by respiratory enzymes

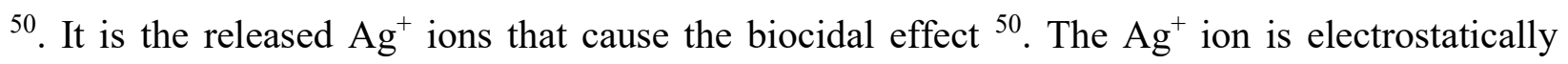
attracted to the negatively charged cell wall. In particular, the $\mathrm{Ag}^{+}$ion binds with the purine and pyrimidine base pairs, rapturing the H-bonds in the base pairs, which results in denaturing and Deoxyribonucleic acid (DNA) disruption ${ }^{50}$. Such $\mathrm{Ag}^{+}$ion-cell membrane interactions prevent 
DNA replications ${ }^{51}$ and subsequently lead to bacterial death ${ }^{52}$. Additionally, Ag-NPs can induce toxicity via reactive-oxygen-species (ROS) -mediated free radical release, which leads to oxidative stresses and possible bacterial death. Therefore, the PMHS molecule may offer a polymeric matrix for holding and presumably triggering controllable $\mathrm{Ag}^{+}$release to kill microorganisms via the oligodynamic effect. It should be noted that $\mathrm{Ag}^{+}$ion of concentrations, 1-10 ppm (commonly measured by Inductively coupled plasma mass spectrometry (ICP-MS)) are known to impact antibactial property without adverse effect on mammalian cell ${ }^{53-55}$. However, $\mathrm{Ag}^{+}$release kinetics and cytotoxic impact studies, for example on fibroblasts cell lines, are beyond the scope of current work and would be reported in our future contribution.

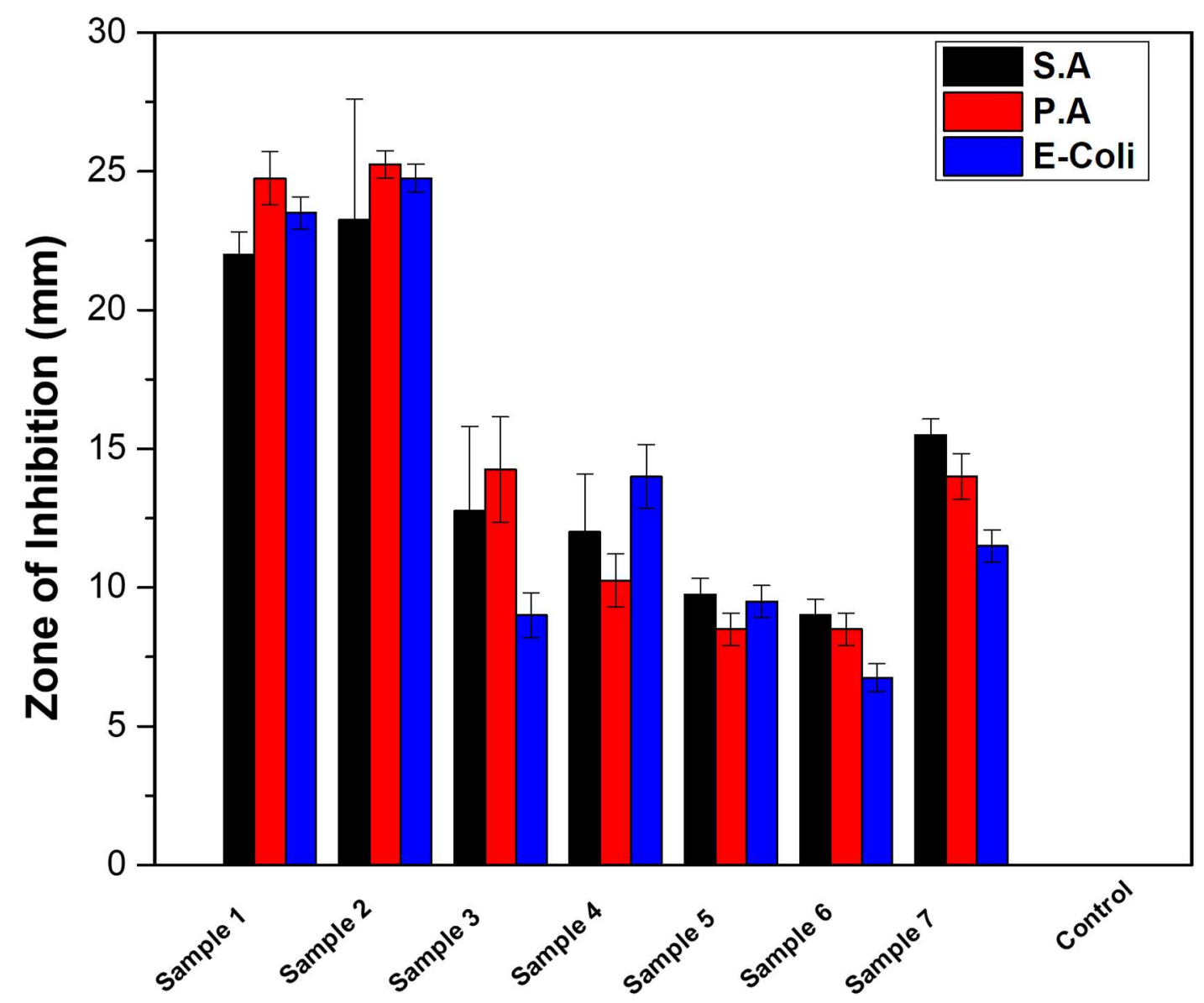


Figure 10. Graphical representation of zone of inhibition of Ag-PMHS nanocomposite against model bacteria. Sample $1\left(\mathrm{Ag}^{+} / \mathrm{Si}-\mathrm{H}\right.$ of $\left.50: 1\right)$; sample 2 $\left(\mathrm{Ag}^{+} / \mathrm{Si}-\mathrm{H}\right.$ of $\left.50: 2\right)$; sample $3\left(\mathrm{Ag}^{+} / \mathrm{Si}-\mathrm{H}\right.$ of $\left.50: 30\right)$; sample $4\left(\mathrm{Ag}^{+} / \mathrm{Si}-\mathrm{H}\right.$ of $\left.50: 40\right)$; sample $5\left(\mathrm{Ag}^{+} / \mathrm{Si}-\mathrm{H}\right.$ of 50:50); sample $6\left(\mathrm{Ag}^{+} / \mathrm{Si}-\mathrm{H}\right.$ of $\left.2: 50\right)$; sample $7\left(\mathrm{Ag}^{+} / \mathrm{Si}-\mathrm{H}\right.$ of 1:50); Control (mineral spirit + PMHS). (Error bars represent SD (standard deviations), and data are from three independent experiments).

Anti-biofouling and biofilm inhibition assay: Bacterial adhesion reduction was performed by two methods. First, by anti-biofouling study; and second, by biofilm inhibition study. Note that limited incubation time was used for the anti-biofouling study. It appears water repellency of most of the superhydrophobic surfaces are lost over time, due to fragility of the surface micro/nano structures and fast surface chemistry degradation ${ }^{56}$. For example, the water roll-off property of a bioresin-based superhydrophobic coating was lost within 6-24 h, leading to colonization by P. A, S.A and E-coli bacteria. Similarly, gram (+ve) S.A cells completely colonized superhydrophobic titanium surface after $18 \mathrm{~h}$ incubation period ${ }^{13}$. By contrast, it seems reports on limited incubation time ( 30 min- $3 \mathrm{~h}$ ), have demonstrated effectiveness of superhydrophobic coating at inhibiting bacterial attachment $\mathrm{t}^{23-25,57-58}$.

Anti-biofouling performance was evaluated by determining the relative bacterial adhesion reduction using the following equation ${ }^{59}$.

$\mathrm{R}(\%)=\left[\frac{(A-B)}{A}\right] \times 100$

where $\mathrm{R}$ is the bacterial reduction (\%), A the number of bacteria colonies $/ \mathrm{cm}^{2}$ on anodized $\mathrm{Al}$ substrate ((AAO/Al), used as control sample), and $\mathrm{B}$ the number of bacteria colonies $/ \mathrm{cm}^{2}$ on 
superhydrophobic AAO/Al sample (04Sil-AgP-NcAAO) having CA of $155 \pm 0.4^{\circ}$. It must be reiterated that the most promising sample (having $\mathrm{Ag}+/ \mathrm{Si}-\mathrm{H}$ molar ratio of 50:2), which exhibited both superhydrophobic and high adhesive properties, was used as test sample for the antibiofouling study. Such dual action superhydrophobic-biocide, is likely to possess excellent bacterial repellency and inhibits bacterial attachment, even after loss of superhydrophobicity. Figure 11 shows the graphical representation of bacterial adhesion $/ \mathrm{cm}^{2}$ reduction for the model bacteria of S.A, P.A, and E-coli. The number of S.A colonies on AAO/Al and the superhydrophobic AAO/Al sample (04Sil-AgP-NcAAO) were $6.5 \times 10^{7}$ and $4.5 \times 10^{5}$, respectively. It is worthy of note that bacteria colonies on the superhydrophobic AAO/Al sample (04Sil-AgP-NcAAO) are two orders less than those on the control sample surfaces (AAO/Al), representing a $2.2 \log$ and $99.3 \%$ S.A reduction. Similar trend was observed for both gram (-ve) P.A and E-coli bacteria. The number of P.A bacterium that colonized the control sample(AAO/Al), was $5.0 \times 10^{6}$, compared to $5.0 \times 10^{4}$, on superhydrophobic AAO/Al sample (04Sil-AgP-NcAAO). Representing a two order of magnitude lower, a 2 log reduction and $99.0 \%$ P.A bacterium reduction. In the case of E- coli, $5.0 \times 10^{6}$ colonies were observed on control sample $(\mathrm{AAO} / \mathrm{Al})$, as against $2.5 \times 10^{4}$ bacterial colonies on the superhydrophobic $\mathrm{AAO} / \mathrm{Al}$ sample (04Sil-AgPNcAAO). Clearly, superhydrophobic AAO/Al sample (04Sil-AgP-NcAAO) was most effective at inhibiting E-coli colonies compared to the other bacteria, with a $2.3 \log$ reduction factor and a 99.5 $\%$ adhesion reduction efficiency. However, it should be mentioned that less bacterial adhesion reduction are observed for non Ag-based superhydrophobic coatings. For example, in the work of Meier, $\mathrm{M}$ et $\mathrm{al}^{23}$, superhydrophobic filamented silicone (having $\mathrm{CA} \sim 164 \pm 5^{\circ}$ ) exhibited E-coli bacterium adhesion reduction of $84 \pm 5 \%$, under $3 \mathrm{~h}$ incubation, while superhydrophobic rod-like silicone (having $\mathrm{CA} \sim 168 \pm 4^{\circ}$ ) showed E-coli bacterium reduction of $79 \pm 7 \%$, under same 
condition. Similar trend was also observed for gram (+ve) S. epidermidis. Superhydrophobic filamented silicone, exhibited adhesion reduction of $95 \pm 3 \%$, while superhydrophobic rod-like silicone showed a reduction of $88 \pm 7 \%{ }^{23}$. In a related study by Crick. C.R., et $\mathrm{al}^{24}$, superhydrophobic silicone elastomer (with $\mathrm{CA} \sim 168^{\circ}$ ), resulted in $79 \%$ and $58 \%$ adhesion reduction for both gram (-ve) E-coli, and gram (+ve) S.A, respectively. Interestingly, in our case, the incorporation of $\mathrm{Ag}$ in the superhydrophobic surface that provided a CA of $155 \pm 0.4^{\circ}$, showed bacterial reduction efficiency of $99.3 \%, 99.0 \%$ and $99.5 \%$ for the S.A, P.A and E-coli bacteria respectively. However, while direct comparison of different reported results must be treated with caution, as differences may arise owing to experimental conditions, these results somehow corroborate our hypothesis that antibacterial Ag-NPs incorporated in superhydrophobic coatings, can enhance the over all effectiveness of bacterial adhesion reduction.

Note that gram (-ve) bacteria such as E-coli and P.A are ubiquitous pathogens in biofilms even on dry inanimate surfaces ${ }^{60-62}$. Therefore, evaluating the superhydrophobic AAO/Al sample (04Sil$\mathrm{AgP}-\mathrm{NcAAO}$ )'s ability to inhibit biofilm growth is essential. Consequently, SEM was utilized to study the biofilm formation ${ }^{63}$. It has been reported that biofilm maturation begins after $24 \mathrm{~h}$ of incubation ${ }^{64}$, henced $48 \mathrm{~h}$ incubation time was utilized to evaluate biofilm growth. As shown in Figure 11 (inset), the entire surface area of $\mathrm{AAO} / \mathrm{Al}$ (uncoated AAO) is covered by the biofilm. By contrast, the biofilm is not observed on the superhydrophobic AAO/Al sample (04Sil-AgPNcAAO), except a few bacteria scattered over the surface. 


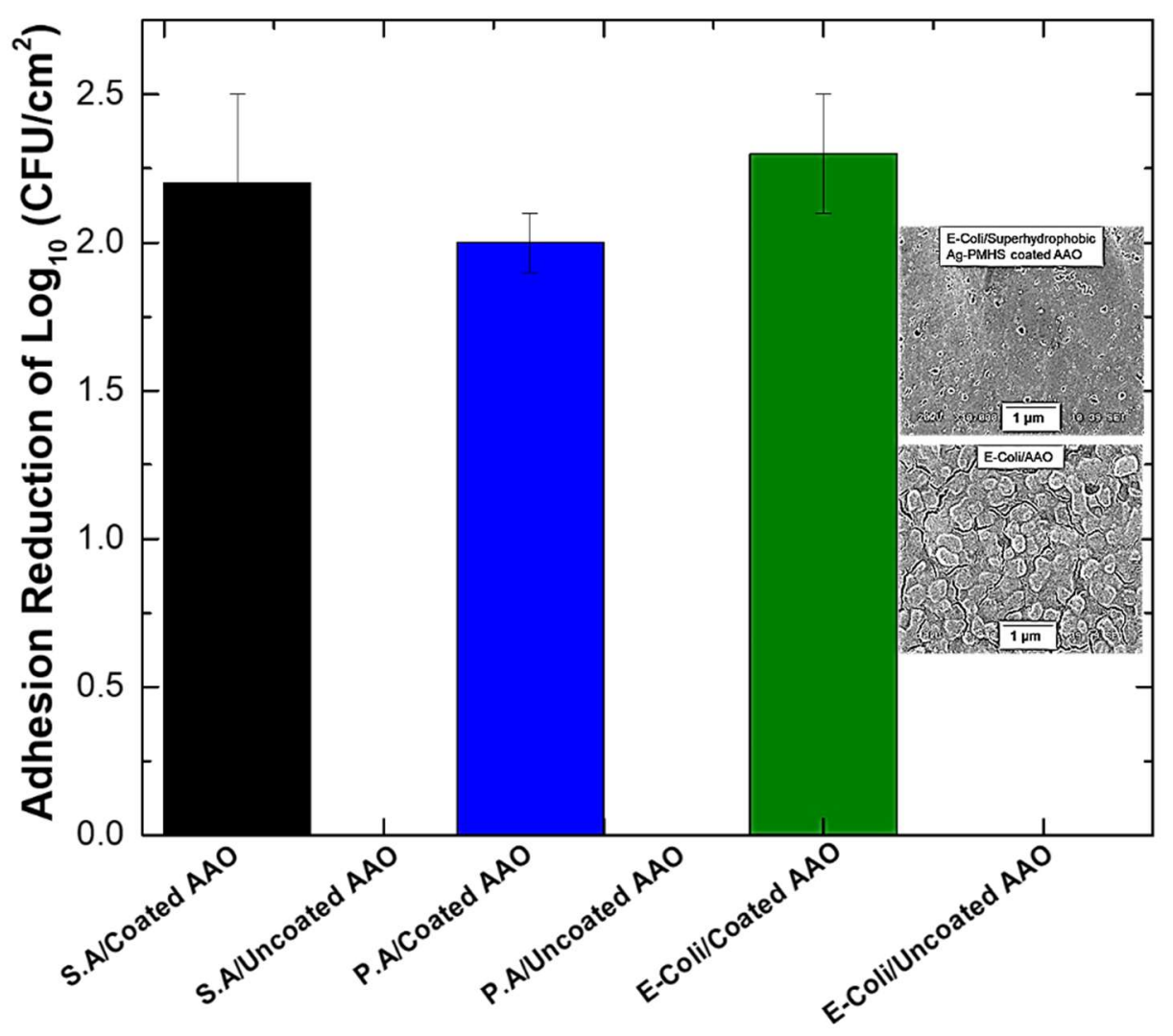

Figure. 11: Adhesion reduction of bacteria (S.A, P.A, or E-coli) on superhydrophobic AAO/Al sample (04Sil-AgP-NcAAO); and control sample (AAO/Al). Data represent multiple independent experiments. Inset: SEM micrograph of E-coli biofilm on superhydrophobic AAO/Al sample (Top); and control sample (AAO/Al) (Bottom).

It is noteworthy that the superhydrophobic $\mathrm{AAO} / \mathrm{Al}$ sample (04Sil-AgP-NcAAO) lost its water roll-off property after $3 \mathrm{~h}$ of being in contact with bacteria. The complex mechanism for bacterial attachment on superhydrophobic coatings, comprising cell adhesion, Van der Waals interactions and activation of quorum sensing molecules, are well acknowledged ${ }^{65}$. This necessitates the need 
for further detailed studies to establish the correlations between bacteria type, surface chemistry and surface morphology ${ }^{66}$. Nevertheless, it is very likely, bacteria in contact with Ag-PMHS nanocomposites release bacterial secretions (biopolymers, $B$ lactamases, and other enzymes) ${ }^{47}$ composed of hydrophilic ligands and proteins $(\mathrm{N}-\mathrm{H}, \mathrm{O}-\mathrm{H}$, and $\mathrm{C}=\mathrm{O})$ that alter the surface chemistry of the superhydrophobic $\mathrm{AAO} / \mathrm{Al}$ sample (04Sil-AgP-NcAAO). Interestingly, the sample regained its water roll-off property (with an average CA of $155 \pm 5.0^{\circ}$ ) after 3 days of air exposure, presumably due to the evaporation of the hydrophilic ligands. It is likely that 04Sil$\mathrm{AgP}-\mathrm{NcAAO}$ exists in the Wenzel wetting state at a high hydrophilic ligand concentration but in the Cassie-Baxter wetting state at a lower hydrophilic ligand concentration. Therefore, the bacterial adhesion reduction observed on superhydrophobic AAO/Al sample, may presumably be facilitated by leachable $\mathrm{Ag}^{+}$ions during the Wenzel state. However, for frequently touched surface applications, where the evaporation of the hydrophilic ligand is possible owing to excess dry air, the Cassie-Baxter state can be re-established to facilitate superhydrophocity. Note that PMHS coated on 120 min anodized $\mathrm{Al}$ exhibited a lower water CA of $123 \pm 3.1^{\circ}$. Therefore bacterial adhesion reduction study was not performed. Such study would be explored in our future contribution.

To further explore the stability of the superhydrophobic sample, a 3-month saline water (3.5 wt.\% $\mathrm{NaCl}, \mathrm{pH}=7.4$ immersion study was performed. As shown in Figure 12, the CA was well above $150^{\circ}$ after 90 days of saline water immersion. This signifies that the coating has a long-lasting stability in a physiological solution ( $\mathrm{pH}$ 7.4), typically found in mammalia cells. 


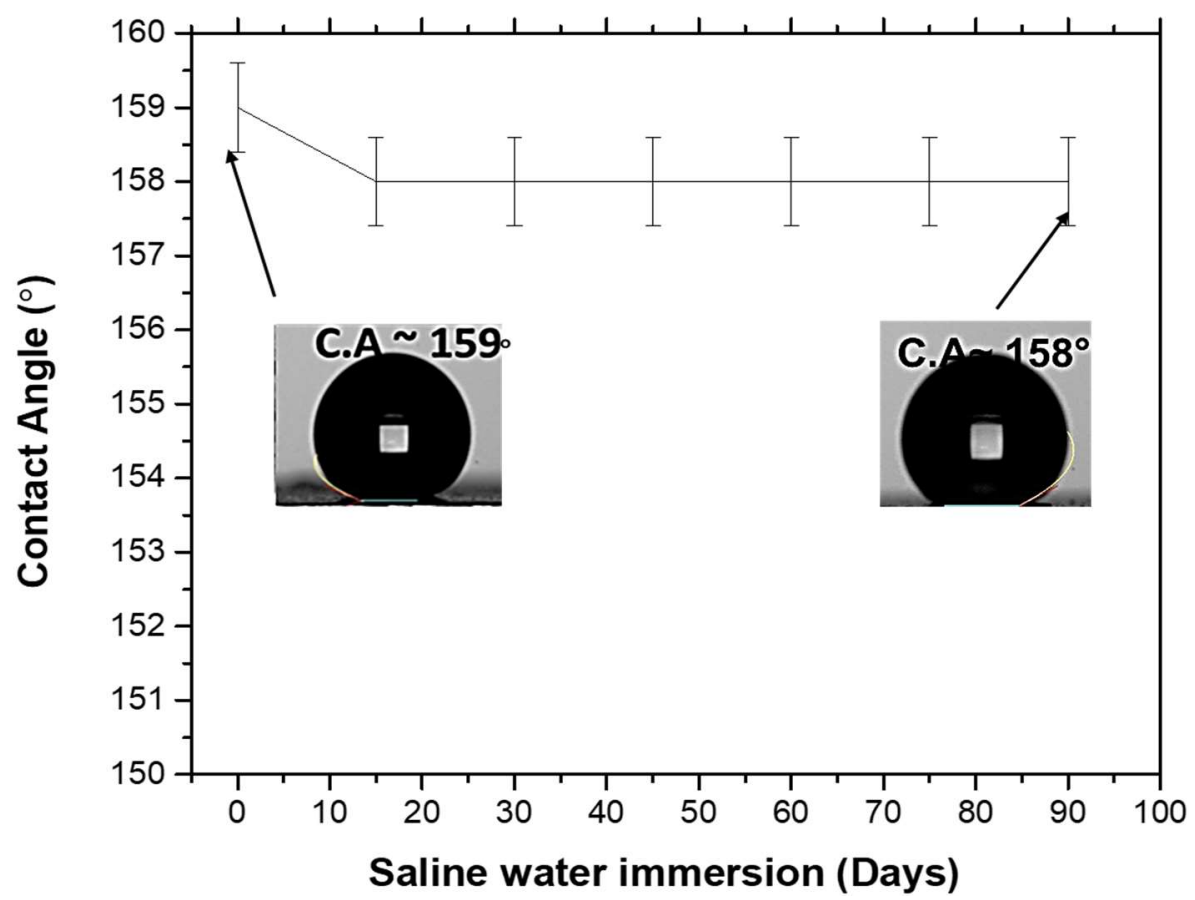

Figure 12. Water contact angle of the superhydrophobic sample with time of immersion in $3.5 \mathrm{wt} \% \mathrm{NaCl}$ solutions. CA was measured after drying samples for $2 \mathrm{~h}$ at $55^{\circ} \mathrm{C}$.

In general, the superhydrophobic sample exhibits both bactericidal and anti-biofouling properties. The bactericidal effect is observed owing to the possible release of $\mathrm{Ag}^{+}$ions that electrostatically interact with the negatively charged cell wall of bacteria, to inactivate it. The anti-biofouling effect is achieved owing to the superhydrophobic property, induced by the combined effects of nanomicro roughness (achieved by Ag-NPs and anodization) and the presence of $-\mathrm{CH}_{3}$ ligand from PMHS. Due to the superhydrophobicity, water has a minimum contact area with the surface, hence a weaker bacterial interaction would be expected on such surfaces. Therefore, it would be favorable 
for bacteria to remain in solution and roll off the surface when tilted rather than adhere to the superhydrophobic surface ${ }^{67}$.

\section{CONCLUSIONS}

In this study, a simple two-step approach was deployed to fabricate Ag-PMHS nanocomposite coatings on anodized Al. The as-synthesized Ag-PMHS nanocomposite coating demonstrated excellent antimicrobial properties against clinically relevant planktonic bacteria, with ZOI values of $25.3 \pm 0.5,24.8 \pm 0.5$, and $23.3 \pm 3.6 \mathrm{~mm}$ for P.A, E-coli, and S.A, respectively. The Ag-PMHS nanocomposite coating exhibited a water CA of $159 \pm 0.5^{\circ}$, providing an excellent anti-biofouling property with bacterial adhesion reductions of $99.0 \%, 99.5 \%$, and $99.3 \%$ for P.A, E-coli, and S.A, respectively. Stability study demonstrated a stable water CA of $158^{\circ}$ after 90 days of immersion in saline water $(3.5$ wt.\% $\mathrm{NaCl}, \mathrm{pH}=7.4)$. Remarkably, the superhydrophobic $\mathrm{Ag}-$ PMHS nanocomposite coating on anodized Al exhibited excellent scratch resistance and strong adhesion property. Overall, Ag-PMHS nanocomposite coating on anodized Al provides a promising and excellent candidate for potential use as antimicrobial touch surfaces to reduce the prevalence of nosocomial infections.

\section{AUTHOR INFORMATION}

Corresponding Author

*Corresponding author: dilip_sarkar@uqac.ca

The authors declare no competing financial interest.

\section{ACKNOWLEDGMENTS}


We acknowledge the financial support from Fonds de recherche du Québec - Nature et technologies (FRQNT) under the grant number 2018-LU-210883.

\section{Supporting Information}

\section{Table of Content:}

Figure S1: ATR- FTIR spectra of Ag-PMHS nanocomposite having a molar ratio of $\mathrm{Ag}^{+} / \mathrm{Si}-\mathrm{H}$ of 50:2.0 coated on $\mathrm{AAO} / \mathrm{Al}(\mathrm{AgP}-\mathrm{NcAAO})$; and $0.4 \% \mathrm{w} / \mathrm{v}$ silicone incorporated in AgP-NcAAO (04Sil-AgP-NcAAO) respectively. The increased intensity of siloxane groups in the FTIR peaks for $04 \mathrm{Sil}-\mathrm{AgP}-\mathrm{NcAAO}$ compared to $\mathrm{AgP}-\mathrm{NcAAO}$ signify the role of RTV siloxane in increasing the monodentate bonding between the $\mathrm{Si}-\mathrm{O}-\mathrm{Si}$ group and the $\mathrm{AAO} / \mathrm{Al}$.

Table S1: Contact angle measurements of Ag-PMHS nanocomposites at different molar ratio on various $\mathrm{Al}$ substrates. Contact angle of the coatings on $\mathrm{AAO}$ increased linearly with increasing Ag:PMHS molar ratio.

Table S2: Grade of adhesive bonding on tested samples. The Ag-PMHS nanocomposite coating on the as- received $\mathrm{Al}$, exhibited the lowest grade of $0 \mathrm{~B}$, while the $\mathrm{Ag}-\mathrm{PMHS}$ nanocomposite coating on $\mathrm{AAO}$ exhibited grades between $4 \mathrm{~B}$ and 5B. Interestingly, after 90 days of saline immersion, the Ag-PMHS nanocomposite coating on AAO (Table S 2D) was still resistant to scratch with adhesive bonding Grade 5B. 
Video S1: Demonstration of water roll-off property of superhydrophobic AAO/Al sample (04SilAgP-NcAAO). The AgP-NcAAO mantains its superhydrophobic property even after loading with $0.4 \%$ w/v RTV silicone (04Sil-AgP-NcAAO).

\section{REFERENCES}

1. O'Toole, G.; Kaplan, H. B.; Kolter, R., Biofilm formation as microbial development. Annual Reviews in Microbiology 2000, 54 (1), 49-79.

2. Hasan, J.; Hasan, J.; Crawford, R. J.; Ivanova, E. P., Antibacterial surfaces: the quest for a new generation of biomaterials. Trends in biotechnology 2013, 31 (5), 295-304.

3. Taunk, A.; Chen, R.; Iskander, G.; Ho, K. K. K.; Black, D.; Willcox, M.; Kumar, N., Dual-Action Biomaterial Surfaces with Quorum Sensing Inhibitor and Nitric Oxide To Reduce Bacterial Colonization. Acs Biomaterials Science \& Engineering 2018, 4 (12), 4174-4182.

4. Algburi, A.; Comito, N.; Kashtanov, D.; Dicks, L. M.; Chikindas, M. L., Control of biofilm formation: antibiotics and beyond. Appl. Environ. Microbiol. 2017, 83 (3), e02508-16.

5. Rabih, O. D., Device-Associated Infections: A Macroproblem That Starts with Microadherence. Clinical Infectious Diseases 2001, 33 (9), 1567-1572.

6. Fair, R. J.; Tor, Y., Antibiotics and bacterial resistance in the 21st century. Perspectives in medicinal chemistry 2014, 6, PMC. S14459.

7. Awan, A. B.; Schiebel, J.; Böhm, A.; Nitschke, J.; Sarwar, Y.; Schierack, P.; Ali, A., Association of biofilm formation and cytotoxic potential with multidrug resistance in clinical isolates of Pseudomonas aeruginosa. EXCLI journal 2019, 18, 79.

8. Alexander, S.; Eastoe, J.; Lord, A. M.; Guittard, F. d. r.; Barron, A. R., Branched hydrocarbon low surface energy materials for superhydrophobic nanoparticle derived surfaces. ACS applied materials \& interfaces 2015, 8 (1), 660-666.

9. Han, K.; Park, T. Y.; Yong, K.; Cha, H. J., Combinational Biomimicking of Lotus Leaf, Mussel, and Sandcastle Worm for Robust Superhydrophobic Surfaces with Biomedical Multifunctionality: Antithrombotic, Antibiofouling, and Tissue Closure Capabilities. ACS applied materials \& interfaces 2019, 11 (10), 9777-9785.

10. Morán, M. C.; Ruano, G.; Cirisano, F.; Ferrari, M., Mammalian cell viability on hydrophobic and superhydrophobic fabrics. Materials Science and Engineering: C 2019, 99, 241-247.

11. Sousa, C.; Rodrigues, D.; Oliveira, R.; Song, W.; Mano, J. F.; Azeredo, J., Superhydrophobic poly (Llactic acid) surface as potential bacterial colonization substrate. AMB express 2011, 1 (1), 34.

12. Ellinas, K.; Tserepi, A.; Gogolides, E., Durable superhydrophobic and superamphiphobic polymeric surfaces and their applications: A review. Advances in colloid and interface science 2017, 250, 132-157.

13. Fadeeva, E.; Truong, V. K.; Stiesch, M.; Chichkov, B. N.; Crawford, R. J.; Wang, J.; Ivanova, E. P., Bacterial retention on superhydrophobic titanium surfaces fabricated by femtosecond laser ablation. Langmuir 2011, 27 (6), 3012-3019.

14. Papadopoulos, P.; Mammen, L.; Deng, X.; Vollmer, D.; Butt, H.-J., How superhydrophobicity breaks down. Proceedings of the National Academy of Sciences 2013, 110 (9), 3254-3258. 
15. Zhang, M.; Wang, P.; Sun, H.; Wang, Z., Superhydrophobic surface with hierarchical architecture and bimetallic composition for enhanced antibacterial activity. ACS applied materials \& interfaces 2014, 6 (24), 22108-22115.

16. Heinonen, S.; Huttunen-Saarivirta, E.; Nikkanen, J.-P.; Raulio, M.; Priha, O.; Laakso, J.; Storgårds, E.; Levänen, E., Antibacterial properties and chemical stability of superhydrophobic silver-containing surface produced by sol-gel route. Colloids and Surfaces A: Physicochemical and Engineering Aspects 2014, 453, 149-161.

17. Wang, Z.; Ou, J.; Wang, Y.; Xue, M.; Wang, F.; Pan, B.; Li, C.; Li, W., Anti-bacterial superhydrophobic silver on diverse substrates based on the mussel-inspired polydopamine. Surface and Coatings Technology 2015, 280, 378-383.

18. Ozkan, E.; Crick, C. C.; Taylor, A.; Allan, E.; Parkin, I. P., Copper-based water repellent and antibacterial coatings by aerosol assisted chemical vapour deposition. Chemical science 2016, 7 (8), 51265131.

19. Xiao, Z.-Y.; Huang, S.-X.; Zhai, S.-R.; Zhai, B.; Zhang, F.; An, Q.-D., PMHS-reduced fabrication of hollow Ag-SiO 2 composite spheres with developed porosity. Journal of Sol-Gel Science and Technology 2015, 75 (1), 82-89.

20. Dag, O.; Henderson, E. J.; Wang, W.; Lofgreen, J. E.; Petrov, S.; Brodersen, P. M.; Ozin, G. A., Spatially Confined Redox Chemistry in Periodic Mesoporous Hydridosilica-Nanosilver Grown in Reducing Nanopores. Journal of the American Chemical Society 2011, 133 (43), 17454-17462.

21. Zhai, S.-R.; Shao, X.; Zhou, D.; Zhai, B.; An, Q.-D., Sol-gel synthesis of nanosilver embedded hybrid materials using combined organosilica precursors. Journal of sol-gel science and technology 2012, 62 (3), 281-286.

22. Shao, X.; Zhai, S.-R.; Zhai, B.; An, Q.-D., Ag+/MPTMS/PMHS-mediated two-step acid-base synthesis of hybrid materials with embedded nanosilver. Journal of sol-gel science and technology 2013, 66 (2), 264-273.

23. Meier, M.; Dubois, V.; Seeger, S., Reduced bacterial colonisation on surfaces coated with silicone nanostructures. Applied Surface Science 2018, 459, 505-511.

24. Crick, C. R.; Ismail, S.; Pratten, J.; Parkin, I. P., An investigation into bacterial attachment to an elastomeric superhydrophobic surface prepared via aerosol assisted deposition. Thin Solid Films 2011, 519 (11), 3722-3727.

25. Privett, B. J.; Youn, J.; Hong, S. A.; Lee, J.; Han, J.; Shin, J. H.; Schoenfisch, M. H., Antibacterial fluorinated silica colloid superhydrophobic surfaces. Langmuir 2011, 27 (15), 9597-9601.

26. Bahrami, A.; Mokarram, R. R.; Khiabani, M. S.; Ghanbarzadeh, B.; Salehi, R., Physico-mechanical and antimicrobial properties of tragacanth/hydroxypropyl methylcellulose/beeswax edible films reinforced with silver nanoparticles. International journal of biological macromolecules 2019, 129, 11031112.

27. Siddaramanna, A.; Saleema, N.; Sarkar, D., A versatile cost-effective and one step process to engineer ZnO superhydrophobic surfaces on Al substrate. Applied Surface Science 2014, 311, 182-188.

28. Xiong, J.; Sarkar, D. K.; Chen, X. G., Ultraviolet-Durable Superhydrophobic Nanocomposite Thin Films Based on Cobalt Stearate-Coated TiO2 Nanoparticles Combined with Polymethylhydrosiloxane. ACS Omega 2017, 2 (11), 8198-8204.

29. Zhang, J.; Hu, X.; Zhang, J.; Cui, Y.; Yuan, C.; Ge, H.; Chen, Y.; Wu, W.; Xia, Q., A fast thermal-curing nanoimprint resist based on cationic polymerizable epoxysiloxane. Nanoscale research letters 2012, 7 (1), 380.

30. Sarkar, D.; Brassard, D.; El Khakani, M.; Ouellet, L., Dielectric properties of sol-gel derived high-k titanium silicate thin films. Thin Solid Films 2007, 515 (11), 4788-4793.

31. Scheschkewitz, D.; Böhme, U., Functional molecular silicon compounds. Springer: 2014. 
32. Corriu, R. J.; Lanneau, G. F.; Perrot-Petta, M.; Nehta, V. D., A new and mild access to Nfunctionalized formamido and thioformamido compounds using hypervalent silicon hydrides. Tetrahedron Letters 1990, 31 (18), 2585-2588.

33. Pope, E.; Mackenzie, J., Sol-gel processing of silica: II. The role of the catalyst. Journal of noncrystalline solids 1986, 87 (1-2), 185-198.

34. Sharma, V. K.; Yngard, R. A.; Lin, Y., Silver nanoparticles: green synthesis and their antimicrobial activities. Advances in colloid and interface science 2009, 145 (1-2), 83-96.

35. Santipanusopon, S.; Riyajan, S.-A., Effect of field natural rubber latex with different ammonia contents and storage period on physical properties of latex concentrate, stability of skim latex and dipped film. Physics Procedia 2009, 2 (1), 127-134.

36. Momen, G.; Farzaneh, M.; Jafari, R., Wettability behaviour of RTV silicone rubber coated on nanostructured aluminium surface. Applied Surface Science 2011, 257 (15), 6489-6493.

37. Alkire, R. C.; Gogotsi, Y.; Simon, P., Nanostructured materials in electrochemistry. John Wiley \& Sons: 2008.

38. Kikuchi, T.; Takenaga, A.; Natsui, S.; Suzuki, R. O., Advanced hard anodic alumina coatings via etidronic acid anodizing. Surface and Coatings Technology 2017, 326, 72-78.

39. Liou, T.-H.; Chang, F.-W.; Lo, J.-J., Pyrolysis kinetics of acid-leached rice husk. Industrial \& engineering chemistry research 1997, 36 (3), 568-573.

40. Brassard, J.-D.; Sarkar, D. K.; Perron, J., Synthesis of monodisperse fluorinated silica nanoparticles and their superhydrophobic thin films. ACS applied materials \& interfaces 2011, 3 (9), 3583-3588.

41. Masuda, H.; Masuda, H.; Fukuda, K., Ordered metal nanohole arrays made by a two-step replication of honeycomb structures of anodic alumina. Science (New York, N.Y.) 1995, 268 (5216), 14661468.

42. Wenzel, R. N., Resistance of solid surfaces to wetting by water. Industrial \& Engineering Chemistry 1936, 28 (8), 988-994.

43. Cassie, A.; Baxter, S., Wettability of porous surfaces. Transactions of the Faraday society 1944, 40, 546-551.

44. Li, J.; Fan, L.; Wong, C.-P.; Lambert, F. C., Insulator coating and method for forming same. Google Patents: 2010.

45. Brassard, J.-D.; Laforte, J.-L.; Blackburn, C.; Perron, J.; Sarkar, D., Silicone based superhydrophobic coating efficient to reduce ice adhesion and accumulation on aluminum under offshore arctic conditions. Ocean Engineering 2017, 144, 135-141.

46. Poberžnik, M.; Kokalj, A., Implausibility of bidentate bonding of the silanol headgroup to oxidized aluminum surfaces. Applied Surface Science 2019, 492, 909-918.

47. Milionis, A.; Loth, E.; Bayer, I. S., Recent advances in the mechanical durability of superhydrophobic materials. Advances in colloid and interface science 2016, 229, 57-79.

48. Ho, P. L.; Ong, H. K.; Teo, J.; Ow, D. S.-W.; Chao, S. H., HEXIM1 peptide exhibits antimicrobial activity against antibiotic resistant bacteria through guidance of cell penetrating peptide. Frontiers in microbiology 2019, 10, 203.

49. Wayne, P., Clinical and laboratory standards institute. Performance standards for antimicrobial susceptibility testing. 2011.

50. Banerjee, S. L.; Potluri, P.; Singha, N. K., Antimicrobial cotton fibre coated with UV cured colloidal natural rubber latex: A sustainable material. Colloids and Surfaces A: Physicochemical and Engineering Aspects 2019, 566, 176-187.

51. Zheng, K.; Setyawati, M. I.; Leong, D. T.; Xie, J., Antimicrobial silver nanomaterials. Coordination Chemistry Reviews 2018, 357, 1-17.

52. Percival, S. L.; Salisbury, A.-M.; Chen, R., Silver, biofilms and wounds: resistance revisited. Critical reviews in microbiology 2019, 1-15. 
53. Sikder, P.; Bhaduri, S. B.; Ong, J. L.; Guda, T., Silver (Ag) doped magnesium phosphate microplatelets as next-generation antibacterial orthopedic biomaterials. Journal of Biomedical Materials Research Part B: Applied Biomaterials 2020, 108 (3), 976-989.

54. Menagen, B.; Pedahzur, R.; Avnir, D., Sustained release from a metal-Analgesics entrapped within biocidal silver. Scientific reports 2017, 7 (1), 1-11.

55. Wei, L.; Lu, J.; Xu, H.; Patel, A.; Chen, Z.-S.; Chen, G., Silver nanoparticles: synthesis, properties, and therapeutic applications. Drug discovery today 2015, 20 (5), 595-601.

56. Zhang, X.; Wang, L.; Levänen, E., Superhydrophobic surfaces for the reduction of bacterial adhesion. Rsc Advances 2013, 3 (30), 12003-12020.

57. Hasan, J.; Webb, H. K.; Truong, V. K.; Pogodin, S.; Baulin, V. A.; Watson, G. S.; Watson, J. A.; Crawford, R. J.; Ivanova, E. P., Selective bactericidal activity of nanopatterned superhydrophobic cicada Psaltoda claripennis wing surfaces. Applied microbiology and biotechnology 2013, 97 (20), 9257-9262.

58. Hizal, F.; Rungraeng, N.; Lee, J.; Jun, S.; Busscher, H. J.; Van Der Mei, H. C.; Choi, C.-H., Nanoengineered superhydrophobic surfaces of aluminum with extremely low bacterial adhesivity. ACS applied materials \& interfaces 2017, 9 (13), 12118-12129.

59. Cho, E.; Kim, S. H.; Kim, M.; Park, J.-S.; Lee, S.-J., Super-hydrophobic and antimicrobial properties of Ag-PPFC nanocomposite thin films fabricated using a ternary carbon nanotube-Ag-PTFE composite sputtering target. Surface and Coatings Technology 2019, 370, 18-23.

60. Sambhy, V.; MacBride, M. M.; Peterson, B. R.; Sen, A., Silver bromide nanoparticle/polymer composites: dual action tunable antimicrobial materials. Journal of the American Chemical Society 2006, 128 (30), 9798-9808.

61. Bhatta, D. R.; Hamal, D.; Shrestha, R.; Subramanya, S. H.; Baral, N.; Singh, R. K.; Nayak, N.; Gokhale, S., Bacterial contamination of frequently touched objects in a tertiary care hospital of Pokhara, Nepal: how safe are our hands? Antimicrobial Resistance \& Infection Control 2018, 7 (1), 97.

62. Russotto, V.; Cortegiani, A.; Fasciana, T.; lozzo, P.; Raineri, S. M.; Gregoretti, C.; Giammanco, A.; Giarratano, A., What healthcare workers should know about environmental bacterial contamination in the intensive care unit. BioMed research international 2017, 7, ID. 6905450.

63. Ramage, G.; Walle, K. V.; Wickes, B. L.; López-Ribot, J. L., Biofilm formation by Candida dubliniensis. Journal of clinical microbiology 2001, 39 (9), 3234-3240.

64. Loo, C.-Y.; Young, P. M.; Lee, W.-H.; Cavaliere, R.; Whitchurch, C. B.; Rohanizadeh, R., Superhydrophobic, nanotextured polyvinyl chloride films for delaying Pseudomonas aeruginosa attachment to intubation tubes and medical plastics. Acta biomaterialia 2012, 8 (5), 1881-1890.

65. Naderizadeh, S.; Dante, S.; Picone, P.; Di Carlo, M.; Carzino, R.; Athanassiou, A.; Bayer, I. S., Bioresin-based Superhydrophobic Coatings with Reduced Bacterial Adhesion. Journal of Colloid and Interface Science 2020, 574, 20-32.

66. Naderizadeh, S.; Dante, S.; Picone, P.; Di Carlo, M.; Carzino, R.; Athanassiou, A.; Bayer, I. S., Bioresin-based superhydrophobic coatings with reduced bacterial adhesion. Journal of Colloid and Interface Science 2020, 574, 20-32.

67. Freschauf, L. R.; McLane, J.; Sharma, H.; Khine, M., Shrink-induced superhydrophobic and antibacterial surfaces in consumer plastics. PLoS One 2012, 7 (8), e40987. 